Revista de
Economild
Contemporâned

Articles

\title{
DRIVERS OF SCIENTIFIC-TECHNOLOGICAL PRODUCTION IN BRAZILIAN HIGHER EDUCATION AND RESEARCH INSTITUTIONS
}

\author{
Maria Gabriela Pinheiro Duarte ${ }^{a}$ \\ Eduardo Gonçalves ${ }^{b}$ \\ Flávia Chein ${ }^{c}$ \\ Juliana Gonçalves Taveira ${ }^{d}$
}

\begin{abstract}
${ }^{a}$ Master in Economics Federal University of Juiz de Fora. Juiz de Fora, MG, Brazil. ORCID: https://orcid.org/0000-0003-0605-3632.

'Professor at the Department of Economics, Federal University of Juiz de Fora. Juiz de Fora, MG, Brazil. ORCID: https://orcid.org/0000-0003-2017-3454.

'Professor at the Department of Economics, Federal University of Juiz de Fora. Juiz de Fora, MG, Brazil. ORCID: https://orcid.org/0000-0003-4002-2522.

${ }^{\mathrm{d}}$ Professor at the Department of Economics, Federal University of Juiz de Fora. Governador Valadares, MG, Brazil. ORCID: https://orcid.org/0000-0001-5487-8669.
\end{abstract}

Received on 11 January 2018

Accepted on 01 June 2020

\begin{abstract}
This article estimates a knowledge production function for Brazilian universities, relating their inputs of scientific activity, such as the total of academic and administrative personnel and investments in scientific research, among others, to their outputs, such as the number of publications and patents. The article applies econometric models for count data, such as the Negative Binomial, for the 2003-2011 period. The overall results show that the main determinants of Brazilian scientific and technological production are the size of the university, its nature (whether public or private), the ratio of teaching staff and graduate students, and total investments in research and research support.
\end{abstract}

KEYWORDS: scientific and technological production; higher education institutions; knowledge production function; negative binomial model; Brazil.

JEL CODES: O31; O32; I23.

Correspondência para: Eduardo Gonçalves

Contato: eduardo.goncalves@ufjf.edu.br 


\section{CONDICIONANTES DA PRODUÇÃO CIENTÍFICO- TECNOLÓGICA DE INSTITUIÇÕES DE ENSINO SUPERIOR E PESQUISA BRASILEIRAS}

RESUMO: Este artigo estima uma função de produção de conhecimento para as universidades brasileiras, relacionando insumos da atividade científica, como o total de pessoal acadêmico e administrativo e os investimentos recebidos para o fomento de pesquisa científica, entre outros, ao seu produto, que são as publicações científicas produzidas nessas instituições e as patentes depositadas por elas. Considerando o período de 2003 a 2011, o artigo usa modelos econométricos para dados de contagem, como binomial negativo. A principal contribuição deste estudo é a avaliação dos condicionantes da produção do conhecimento básico e aplicado nos institutos de ensino superior do Brasil. Os resultados mostram que os principais determinantes da produção científica e tecnológica brasileira são: o tamanho da universidade, sua natureza (se pública ou privada), a proporção de professores e estudantes de pósgraduação e investimentos totais e de apoio à pesquisa.

PALAVRAS-CHAVE: produção científica e tecnológica; instituições de ensino superior; função de produção de conhecimento; binomial negativo; Brasil. 


\section{INTRODUCTION}

Universities and educational institutions have a strategic place in National Innovation Systems (NIS). Many experts see the strength of a nation's university system as a robust measure of its ability to maintain its position in the ranking of developed global economies or to fit into such a group. Therefore, the university has become the focus of several studies in recent years. In addition to teaching, the university has expanded its missions in the $21^{\text {st }}$ century to include the production and dissemination of new knowledge, basic and applied research, and the commercialization of that knowledge.

In developed countries, such as England, the United States, and Canada, investment per student has been in continuous decline over the years (BEKHRADNIA, 2004). In the specific case of Brazil, the contrary was valid until 2011. Based on data from the National Institute of Educational Studies and Research (INEP), estimated direct public investment in education per student over the period 2000-2011 increased by almost 39.62\% between 2003 and 2011 (INEP, 2015). This happened together with a large increase in the number of universities and colleges in operation in the country.

Despite the growth trajectory of scientific and technological production by Brazilian universities, Brazil is still at the construction stage of its science and technology (S\&T) system. These institutions play an essential role in creating and diffusing knowledge, with the national private education sector having less weight concerning the R\&D spending, notwithstanding. This increases the strategic role of Brazilian universitiesin the constitution and consolidation of the Brazilian NIS.

Papers that deal directly with Brazilian universities in general address issues such as the efficiency of resource allocation in the university system (FAÇANHA and MARINHO, 1999; 2001; ABIGAIL and SIOW, 2003; COSTA et al., 2015); universitycompany interaction (PÓVOA and RAPINI, 2010; RAPINI, CHIARINI and BITTENCOURT, 2015; GARCIA et al., 2019); and specific studies on Brazilian universities, such as the universities of the state of Paraná (CALDARELLI et al., 2014); the São Paulo State University (MEDEIROS and FARIA, 2006); the Federal University of Piauí (TARGINO and CALDEIRA, 1988); the Federal University of Juiz de Fora (GONÇALVES and CÓSER, 2014). Other studies address the Science and Technology system, highlighting its origin and differences to other countries or focusing on regional issues (NEVES, 2002; LETA; CRUZ, 2003; MENEGHINI, 2001; GREGOLIN, 2005; MACULAN and MELLO, 2009; CHIARINI and VIEIRA, 2012).

Despite the importance of these studies, the objective of this article is to evaluate the drivers of scientific and technological production in Brazilian universities for the period 2003-2011, based on the methodological framework of the knowledge production function. This approach relates inputs from scientific activity, such as 
faculty and capital stock to foster scientific research, to university outputs, such as scientific publications and patent applications. For that, publications in scientific journals are used as an output measure of basic university research and patent applications as an output of applied research.

Due to the weight of public higher education and research institutions and the volume of investments made in these institutions, the main contribution of this study is to evaluate the conditions for the production of basic and applied knowledge in higher education institutes in Brazil. There is a shortage of empirical studies that take into account a wide range of higher education institutions in Brazil and apply appropriate econometric methodologies over a long period.

The main results show that the size of higher education institutions, the relative amount of human resources, and the financial resources invested in the institutions, as well as the quality of graduate programs, are positively associated with the indicators of scientific and technological production. Having identified the drivers, the study provides new perspectives for the implementation of policies aimed at promoting the production of S\&T in the Brazilian university system.

\section{LITERATURE REVIEW}

Etzkowitz et al. (2000) focus their analysis on higher education institutions' growing importance in new knowledge-dependent societies. The authors conceived the triple helix model, which exemplifies the relationships between the academic, governmental, and industrial environments. The Triple Helix model popularized by Etzkowitz and Leydesdorff (1997) involves collaboration between different spheres, including the public sphere (government), the private sector (companies), and the academic (universities and research institutions). In this model, the university performs a mission in addition to the already conventional teaching and research. This mission is to be an active agent in developing the economy, whether through the generation of scientific and technological knowledge. The model focus on increasing the interaction between institutional actors in the innovation systems of industrial economies, with special attention to the role of universities. In the authors' view, universities act as a leader in the relationship with the industry and the government to enhance the exchange of scientific and technological knowledge.

Etzkowitz and Leydesdorff (1997) highlight that the identifying, creating, and commercializing intellectual property has become the objective of several governments for their academic systems. This is because so many governments and private sectors take universities as large reservoirs of potentially marketable knowledge, waiting to be 
transferred to firms, which would then apply such knowledge to products and services. It is expected that universities can generate more applied knowledge of relevance to industrial sectors, spread knowledge, and provide technical support to firms. The role of universities in this new paradigm in society is reinforced, in which these institutions are the agents of technological innovations. Governments facilitate and encourage this transition as an economic development strategy.

Universities and publicly-funded laboratories assume a vital position in innovation systems (NELSON, 1993), although in the NIS approach, the firm has leadership concerning the triple helix model (ETZKOWITZ and LEYDESDORFF, 2000). The weight of universities in the scientific system has not decreased over time because they collaborate with hospitals, industries, and government laboratories (GODIN and GINGRAS, 2000). Among the outputs of the university system are the generation of research that can potentially be absorbed by the productive sector (BRAMWELL and WOLFE, 2008); prototypes of new products and processes (MOWERY and SAMPAT, 2006); entrepreneurship and qualified human resources (ETZKOWITZ and LEYDESDORFF, 2000); long-term basic research; solutions to technical problems (applied research); other services for industry, spin-offs, and start-ups (BRAMWELL and WOLFE, 2008). The productivity of different sectors of a country's economy is related to the pool of available knowledge, meaning that research is essential for regional and national economic growth, through industrial innovation. Researchers, especially in areas such as science and engineering, seek to create new knowledge through academic research.

These products can, broadly speaking, be classified as basic research or applied research. The definition of basic and applied research lies fundamentally in its objectives. According to Stokes (2005), basic research is that which seeks to broaden the understanding of the phenomena of a field of science, while applied research focuses on some need or application on the part of an individual, a group, or a society. The production of new basic knowledge is the main result of basic research developed by higher education institutions. Such research consists of articles, reports, that is, scientific publications in general, which provide scientific and technological information widely used in applied R\&D expenditures. Applied research, on the other hand, has been intensively boosted through government initiatives that seek to stimulate local economic development based on university research. This can happen through the creation of technology parks located close to university research campuses, the creation, and support of business incubators, in addition to the creation of laws that improve university-industry collaboration and technology transfer in NIS. Both the basic and applied dimensions of research, however, are of equal importance. The former increases the productivity of the latter and is compared to a means of entering 
complex technological areas where only the domain of basic science enables successful innovations, like biotechnology - besides being the reason why some firms spend resources even without a guarantee of appropriability (ROSENBERG, 1990).

The concept of NIS can be understood as a set of organizations and institutions that contribute to the effective development of an innovative environment, whether at the sectoral, regional, or national level. According to Nelson (1993), the NIS is an institutional arrangement that involves several components that create an information network intended to boost technological development in specific areas. These are institutional arrangements that articulate with the educational and S\&T system, with the industrial and business sectors and with financial institutions, totaling the agents that are responsible for generating, implementing, and diffusing innovations.

Albuquerque (1996) conceptualized the NIS as "an institutional construction, the product of a planned and conscious action or a sum of unplanned and disjointed decisions, which drives technological progress in complex capitalist economies," thus enabling the functioning of information flows essential to the technological innovation process. These information flows happen with the interaction between the agents, such as firms and their networks of cooperation and interaction; universities and research institutes; teaching institutions; the financial system; legal systems; market and non-market selection mechanisms; and coordination mechanisms and institutions. These components interact with each other, articulate, and have several mechanisms that initiate feedback processes.

It is possible to break the NIS into subsystems taking into account the characteristics and decisions of its economic agents. Such subsystems would be productive, financial, S\&T and R\&D, among other bodies that make up the NIS. Thus, when analyzing an NIS, it is understandable and advisable to focus on a few subsystems, in the case of innovation it is closer to that of research in S\&T and R\&D (NELSON and WINTER, 2005), as well as the creation of scientific knowledge.

In Brazil's particular case, this system is very diversified. It encompasses different bodies, governmental or otherwise, all acting to promote scientific and technological development, such as federal and state bodies fostering scientific and technological activities, and training human resources. Universities and research institutes, both public and private, in turn, are themselves responsible for producing scientific and technological knowledge (NEVES, 2002). This system includes government and private agencies, the public institutional teaching and research network, as well as the private one, which also receives public resources through performance criteria. These institutions are primarily focused on the production of science and technology. On the demand side, there are companies and other instances of society (FIGUEIREDO, 1998). 
Although universities perform similar functions within innovation systems worldwide, the importance of these institutions' role varies considerably from one economy to another, influenced by the domestic industry structure, and the size and structure of research institutes with public funding. For Rapini and Campos (2004), there are national specificities to consider to understand the degree to which the interaction between universities and companies occurs. For example, developing countries have low levels of $\mathrm{R} \& \mathrm{D}$ conducted by companies, which is almost exclusive to universities and public research institutions.

Empirical literature seeks to assess these impacts. Crespi (2007) uses a knowledge production function approach (GRILICHES, 1979). As a dependent variable, the author uses all possible research products, such as publications, articles in journals, books, book chapters, and others. The author concludes that research grants are more beneficial for the production of scientific articles, while the university's internal resources, such as administrative staff, are more important for other types of production, such as the number of patents each university has and citations obtained by the academic staff's articles.

Bolli and Somogyi (2011) analyze the impact of public and private funding on the productivity of the departments of public universities and research institutions in Switzerland. The authors use a production function, in which the dependent variable is the number of publications scientific; the explanatory variables are the total teaching staff and total budget per employee; and which contain dummy variables for the definition of scientific fields. They concluded that both the participation of public and private financing results in increases in the productivity of universities.

Authors such as Hewit-Dundas (2012) and Mowery and Sampat (2005) study the determinants of both basic and applied research and conclude that both are strongly influenced by the size of the educational institution. Chaimovich (2000) categorically states that measures such as the expansion in the number of enrollments and greater investments in infrastructure and trained personnel must be implemented if universities want to remain as major knowledge producers.

According to Hewitt-Dundas (2012), research on the specific determinants of university patenting is still scarce. Several factors affect university patenting (MOWERY and SAMPAT, 2005). One of these is the size of a university, as larger universities tend to have more resources to develop patents and research-based scientific articles. For example, Laundry et al. (2006) conclude that the size of a university is a significant determinant of the exchange of knowledge between university-industry based on a survey of 1554 researchers in Canada. Based on data from university patents for the United States, Bulut and Moschini (2009) and Coupé (2003) found out that the size of a university has a similar influence on patenting, as larger universities have a greater 
structure and receive more investment from both public and private sources. Although many results reaffirm the importance of the size of the university, the work of Fisch et al. (2015), which measures size by the total number of employees and conducts an econometric analysis of the patenting activity of the 300 most important universities in the world, finds no significant effect of this characteristic on the number of patents. According to the authors, the effects of this variable may have been partially captured by another independent variable in the model, such as the number of publications.

Abigail and Siow (2003) study the effect of the federal research fund on the university research output of 68 research universities during 25 years, using the instrumental variable method. The authors used student affiliation to US congressional committees as an instrument for federal R\&D funding. Three measures of the research output are used: published articles, citations, and patents. They find a positive effect of the research fund on the amount of research carried out. If there is an increase of one million dollars, the result for the university is 10 articles and 0.2 more patents. On the other hand, no significant effect was found of the research fund on the dependent variable, that is, the quality of research, measured by citations of articles.

Based on this literature review, it can be concluded that: i) teaching and research institutions are central to the constitution and consolidation of innovation systems; ii) the productivity of basic and applied research depends on the amount of resources allocated; iii) the size of the institutions seems to be a crucial factor for the quantity and quality of S\&T production; iv) the role of universities vary according to the country's history and degree of industrial and economic development; v) the number of empirical studies on the determinants of academic products, in the context of the knowledge production function, is still scarce in the literature, especially in the Brazilian case.

\section{METHODOLOGICAL ISSUES AND DESCRIPTIVE STATISTICS}

Like traditional production functions, which seek to relate the various inputs $\mathrm{X}$ and the final product (output) Y, the knowledge production function approach aims to relate knowledge inputs to its outputs, i.e, patents or scientific publications. The CobbDouglas function is usually one of the most common approaches used in knowledge production literature. When introducing the concept of the knowledge production function, Griliches (1979) specifies a function relating the research product to a stock of knowledge, which, in turn, is determined by current and past R\&D expenditures. Furthermore, measures that affect the knowledge product, such as the research input, take time to affect the measurement of production, in addition to the fact that previous 
R\&D expenses become obsolete and therefore the net capital stock is not simply the sum of investments made in the period (GRILICHES, 1979). Thus, empirical strategies based on production must take into account the time lag of explanatory variables and a method of calculating the capital stock, such as the perpetual inventory method.

In this article, the following knowledge production function is used:

$$
y_{i t}=a+\beta_{1} x_{1 t}+\beta_{2} x_{2 t}+\beta_{3} x_{3 t}+\beta_{4} x_{4 t}+\beta_{5} x_{5 t}+\beta_{6} x_{6 t}+\beta_{7} x_{7 t}+\varepsilon_{i t}
$$

In (1), the variables are as follows:

- $y$ represents the production of knowledge, basic and applied, of the university system, measured alternately in the present study by total publications (PUB) and total patent applications (PAT).

- $a$ is a constant.

- $x_{1}$ is the university size measured by the number of students enrolled in undergraduate courses (STUDENTS). ${ }^{1}$

- $x_{2}$ is the size of postgraduate programs, including Master and Ph.D. courses (PROFperPOSTSTUD).

- $x_{3}$ is the age of the higher education and research institution $(A G E)$.

- $x_{4}$ is a vector of variables that measures the number of postgraduate programs by areas of knowledge (EXACT AND LAND SCIENCES, HUMANITIES, BIOLOGY, and MULTI-DISCIPLINARY AREAS).

- $\quad x_{5}$ is a vector of dummy variables (DQUALITY_EXA, DQUALITY_HUM and DQUALITY_BIO) that evaluate the quality of postgraduate programs (master's and doctorate), represented by the number of courses with grades 6 or 7 awarded by the Brazilian Coordination for the Improvement of Higher Education (CAPES).

- $x_{6}$ is a dummy variable $(P U B L I C)$ that represents the public or private nature of the institution.

- $x_{7}$ represents a vector of dummies variables that measure investments to promote research, whose proxies, alternatively tested, are total investment per member of the teaching staff (TKperPROF), investment in research grants per member of teaching staff (KRperPROF), total investment per student (TKperSTUD), and investment in research grants per student (KRperSTUD).

- $\varepsilon_{i t}$ is an error term.

1 It was inserted in a logarithm form to avoid problems caused by the nature of this measure. 
Subscribers $i$ and $t$ represent the higher education and research institution and the year analyzed, respectively.

Given the use of four alternative measures for investments to promote research, $k$, the Akaike (AIC) and Bayesian (BIC) information criteria are used to confirm which specification presented the best fit. The description of the variables used in the model will be presented in the next section. To mitigate possible problems of endogeneity, the lag of one and two years was tested for the independent variables, except for the age variable of the institution. As the results remain robust, the estimation with variables in level was the only one presented here. ${ }^{2}$

The conditional average for knowledge production is specified as:

$$
E\left(y_{i t} \mid k_{i t}, x_{i t}\right)=\exp \left(\beta k_{i t}+\gamma x_{i t}\right) v_{i}
$$

To estimate models in which scientific production is sought to be explained, as well as patent application data, one must take into account some specific characteristics of these types of data. Publication numbers constitute events, which can be considered count data (WOOLDRIDGE, 2006). Such a counting event refers to the number of times an event occurs in a given period. Besides, published articles assume only integers and positive values and do not have an upper limit value. The values assumed by the variable represent the number of times the event occurred. Therefore, the knowledge production function is estimated using models for counting data.

The phenomenon of overdispersion can occur when the variance of the response variable is greater than the average. In this case, the Poisson distribution assumption for the answer is inadequate, since this model underestimates the dispersion of the dependent variable, presenting both standard error and p-values well below the real. A simple investigation of the dependent variables used in the present study allows us to verify the overdispersion of the data, considering that its average is less than its variance. This dispersion of variables can be confirmed in Tables A1 and A2 in the Appendix.

Therefore, the Negative Binomial model is a more adequate approach when generalizing the Poisson regression model, introducing a dispersion parameter to the estimates. To deal with data overdispersion, the procedure identifies the heterogeneity in the model's observations, adding an extra parameter, which is a function of the unobserved heterogeneity. In the implementation, the modified Binomial Negative model of random effects is used (ALLISON and WATERMAN, 2002), in which

2 The results with lagged variable estimations are available upon request to the authors. 
covariates that vary over time are expressed as deviations from the specific average of each observation unit, that is, of each higher education institution. By introducing this modification, the modified random-effects method relaxes the hypothesis of no correlation between the model's explanatory variables and the error term. We opted to use the modified random-effects method instead of the Fixed Effects Negative Binomial proposed by Hausman, Hall and Griliches (1984), because the latter does not qualify as a true fixed effects method as it fails to control covariates that do not change over time. Thus, this model allows the specific individual variation in the dispersion parameter and not in the conditional average.

It is worth mentioning, however, the large number of higher education institutions that had no scientific production, neither publications nor patent applications in the period analyzed. It is noteworthy that the presence of zeros declines over time, nevertheless. While in 2003 approximately $43 \%$ of the institutions had zero scientific publications, in 2011 this decreased to $22 \%$. Regarding the technological production, the percentage of zeros is even higher, around $79 \%$ of the observations did not present any patent deposit in the period. However, this percentage declines each year, indicating that the production of knowledge in Brazilian institutions is maturing over time.

The database which covers the period 2003 to 2011 was constructed with variables related to both public and private higher education institutions, forming a sample of 235 institutions each year. ${ }^{3}$ Thus, there is a balanced data panel composed of 2,115 observations. This number does not cover all Brazilian institutions, as many of them have not provided information to agencies, such as CNPq and CAPES, which compiled the databases used in this study. The variables used are described in Table 1.

In this work, two measures of university products are tested as a dependent variable: i) the total number of publications made by universities (pub); and ii) the patents deposited by these institutions ( $p a t)$. These proxies of knowledge production are regressed against measures of knowledge inputs, such as university age, the nature of the institution (public or private), total number of enrolled students (a proxy for university size), investments (aid to researchers and promotion of research), scale and quality of the graduate system, and economies of scope in research (number of different postgraduate programs per institution).

The data related to scientific production were found in the Cadernos de Indicadores on the CAPES website (CAPES, 2015), where publications are presented in three ways: articles in journals; book chapters; and complete works in annals. The data on technological production were collected from a database belonging to the National

\footnotetext{
3 A list of these institutions is reported in Appendix (Table A8).
} 
Institute of Intellectual Property (INPI, 2015). According to INPI, patent application data include the invention patent, which are products or processes that meet the requirements of inventive step, novelty and industrial application, and those of utility model, which refers to an object of practical use, or part of it, susceptible to industrial application that presents a new form or disposition involving an inventive act, resulting in a functional improvement in its use or in its manufacture.

The age of the institutions $(A G E)$, that is, the number of years since the higher education and research institution was founded, is used as a control variable. The reason, based on the literature, is that older universities have greater academic production than younger ones (CRESPI, 2007 ). The information was found on the institutions' websites.

A dummy variable called PUBLIC was also included, which aims to verify whether public institutions are more productive than private ones. Public universities are expected to be more productive in the publication of scientific articles and in the application of patents, as they occupy a central position in the Brazilian academic scenario, playing a strategic and historical role in the process of scientific and technological development (NEVES, 2002).

The size of the university was measured by the total number of students enrolled in undergraduate courses each year (STUDENTS). It is expected that the greater the number of students, the greater the university's scientific production (CRESPI, 2007). Large institutions usually receive more investment from public agencies, in addition to having infrastructure that is proportional to their size. These data can be found in the reports of the Higher Education Census, presented by the National Institute of Educational Studies and Research (INEP, 2015).

The variables that measure investments are the research aid granted to researchers divided by students (KRperSTUD) and teaching staff (KRperPROF), and the cumulative total of investment in research promotion at universities, divided by teaching staff (TKperPROF) and students (TKperSTUD). The latter includes the amount spent on scholarships for students in the master's and doctoral programs and the amount spent on scientific initiation scholarships. In regressions, these variables were used on a logarithmic scale because their scale is very different from the rest of the variables. The university's scientific productivity is expected to increase as a result of such a variavel, indicating the return that this type of investment has for the creation of knowledge (CRESPI, 2007).

The investment data used above only reflects part of the investments from public agencies in Brazil, as they do not include investments made by state agencies and other private sources, not publicly available. To minimize a potential bias caused by this measurement error, the inclusion of dummies for the existence of state-level funding 
agencies was tested. They assume a value of 1 if the university belong to the same state of a respective funding agency and zero for everything else. For example, the dummy representing the existence of state resources from FAPEMIG (a funding agency linked to the government of the state of Minas Gerais) assumes a value of 1 in educational institutions in Minas Gerais and zero for other institutions. Dummies are considered for the following state-level funding agencies: ${ }^{4}$ FACEPE (PE), FAPDF (DF), FAPEAM (AM), FAPEAP (AP), FAPEG (GO), FAPEMA (MA), FAPEMAT (TO), FAPEMIG (MG), FAPEPI (PI), FAPERGS (RS), FAPERJ (RJ), FAPERN (RN), FAPERO (RO), FAPESB (BA), FAPESC (SC), FAPESP (SP), FAPESPA (PA), FAPESQ (PB), and FAPPR (PR). The results of the estimates, such as robustness control, are shown in Tables A4 and A5 in the Appendix. This section includes also Tables A5 and A6 that have controls for regions.

The dummy variables DQUALITY_EXA, DQUALITY_HUM, and DQUALITY_ $B I O$ assume a value of 1 if there is at least one graduate program that received grades 6 and/or 7 and zero, otherwise. These grades are given by CAPES for quality of master's and doctoral courses. Therefore, such proxies test the hypothesis that the excellence of graduate programs positively influences the scientific and technological production of universities. This information comes from the CAPES website. In this case, three dummies were created, one for each area of knowledge: Humanities, Exact and Land Sciences, and Biology.

The number of graduate programs is another variable divided by areas of knowledge, which are the same as those listed above, plus the addition of the multidisciplinary area, thus totaling four variables, EXACT AND LAND SCIENCES, HUMANITIES, BIOLOGY, and MULTIDISCIPLINARY. These variables have the function of testing the existence of economies of scope in research in Brazilian universities.

The number of teaching staff divided by the number of students enrolled in strictosensu postgraduate courses (PROFperPOSTSTUD) is used to verify whether the relative size of the postgraduate program impacts scientific productivity. These data were found in GEOCAPES (CAPES, 2015).

Also, a dummy variable (PUBLIC) is inserted to control for differences in knowledge production across higher education institutions with different legal status, whether public and private. It aims to capture institutional or other factors, not captured by the other explanatory variables in this work.

4 The acronym in parentheses refers to the state of the state-level funding agency. 
Regarding the dependent variables, as it can be seen in Table 1, the average number of publications $(P U B)$ by Brazilian institutions in the period was $1,310.37$, with the University of São Paulo (USP) diplaying the highest concentration of publications, with the maximum value of 45,058 publications in 2011. Although USP was the largest producer of publications in the entire period, its share in the total of publications decreased over time. In 2003, approximately $18 \%$ of Brazilian publications in the database were from that institution whereas, in 2011, the percentage fell to $11 \%$, indicating a decrease in the concentration of scientific knowledge production in Brazil in the period. It should also be noted that, in 2011, of the 63 institutions with a higher number of publications than the average for the period, 56 were public and only 7 were private. The minimum value for this variable is 0 , with $30 \%$ of the observations not having scientific publications in the period. The evolution of production in the period 2003-2011, on average, is shown in Figure 1.

Figure 1 - Evolution of the average scientific production of Brazilian higher education and research institutions, 2003-2011

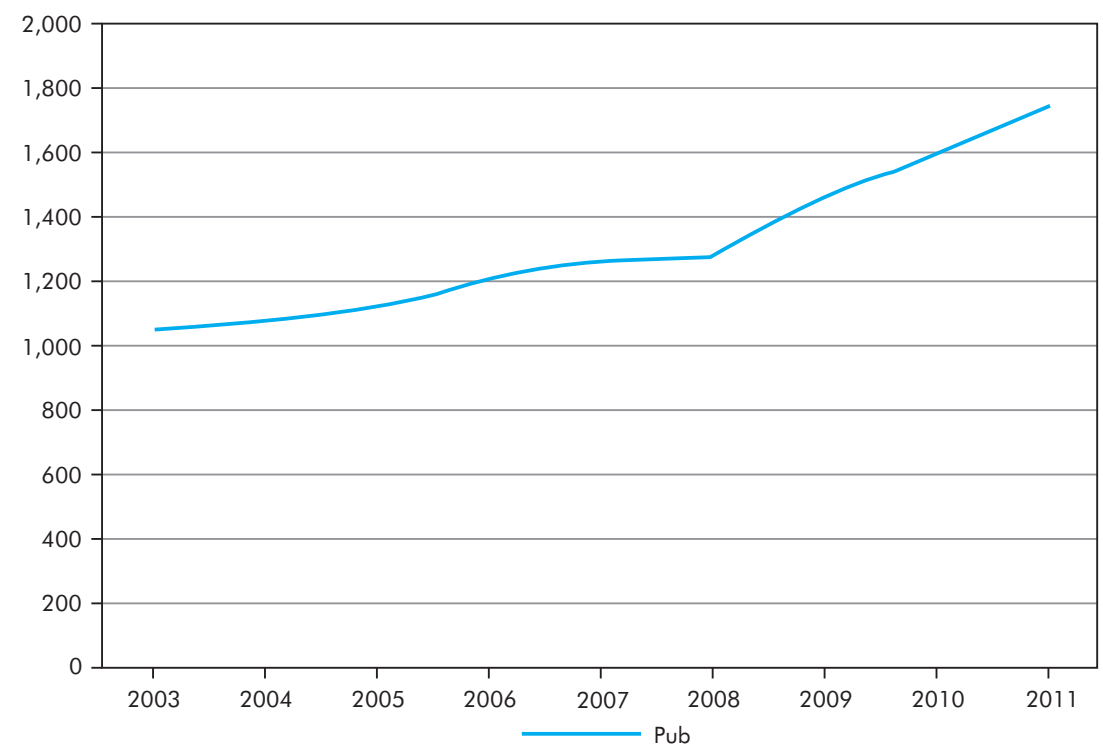

Note: Scientific production includes articles in journals; book chapters; and complete works in annals.

Source: Authors' own elaboration.

The other dependent variable proxy, patents (PAT), has an average of 1.78. Its maximum value is 111 , related to USP in 2011, and its minimum value is 0 , which occurs in almost $80 \%$ of the observations. It is also noteworthy that $84 \%$ of the 
observations produced patent deposits below the national average in the period, with $80 \%$ producing less than 1 deposit over the 9 years of the analysis. Only $16 \%$ have patent volumes above the average, and in 2011, of the 60 institutions with the number of deposits higher than the average, 55 were public and only 5 were private. It is noteworthy, therefore, that most of the country's technological knowledge generation is concentrated in public higher education and research institutions and has grown over the period (Figure 2). Studies such as Colla and Esteves (2013) and Castro and Souza (2012) associated the incentives of Innovation Law No. 10,973 of 2004 to the greater generation of university patents in the period 2005-2010 and the institutionalization of Technological Innovation Centers (NITs) in universities. These played an active role in formalizing, through patents, the technologies developed at universities that led patenting, such as USP, Unicamp, UFRGS, and UFRJ, in addition to promoting greater interaction with society.

On average, the institutions are 36 years old, with some newly created and others 217 years old, such as the Military Engineering Institute (IME). In general, there is a higher average number of institutions with postgraduate programs in the area of Exact and Land Sciences than in Humanities, Biology, and Multidisciplinary sciences, with an average in the period of $3.44,2.64,2.23$ and 0.55 , respectively. The largest number of Exact programs in the sample was at USP, with 68 programs. This is followed by UNESP with 43. UNESP is the institution with the largest number of Humanities, Biology, and Multidisciplinary programs in the sample, with 49 Humanities programs in the period 2008 to 2011, 102 in the Biology in 2005, and 11 Multidisciplinary programs in 2011.

It is also worth mentioning an increase in the number of institutions with at least one postgraduate program, rising from $95 \%$ in 2003 to $100 \%$ in 2011 . Of the 235 institutions in 2003 , around $31 \%$ had at least one Humanities program, $26 \%$ had a postgraduate program in the Exact area, 28\% Biology, and 15\% in the Multidisciplinary area. This percentage rose in 2011 to approximately 55\%, 49\%, 43\%, and 43\%, respectively. Therefore, there was an increase in the number of postgraduate programs in the period.

Regarding investment in the higher education institutions in the sample, it appears that in the period, on average, the total investment per member of the teaching staff (TKperPROF) was $\mathrm{R} \$ 4,882.41 ; 112$ institutions did not receive any investment and the Federal University de Lavras (UFLA) showed the largest investment per member of the teaching staff, $\mathrm{R} \$ 110,852.90$ in 2011 , which corresponded to $5 \%$ of the total investments per member of the teaching staff that year. When the denominator of this variable is a student, it can be seen that the average investment is less than half of the former. The maximum value was approximately $\mathrm{R} \$ 28,695.38$, corresponding to UNIFESP. Regarding investment in research aid, the highest value per member of the 
teaching staff and per student in the period was attributed to IME. It should also be noted that in 2003, $41 \%$ of institutions had a total investment equal to zero. This percentage decreased to $6 \%$ in 2011. In relation to investment in research aid, approximately 56\% of institutions did not receive any aid in 2003 and $8 \%$ in 2011.

Figure 2 - Evolution of the average number of patents filed by Brazilian higher education and research institutions, 2003-2011

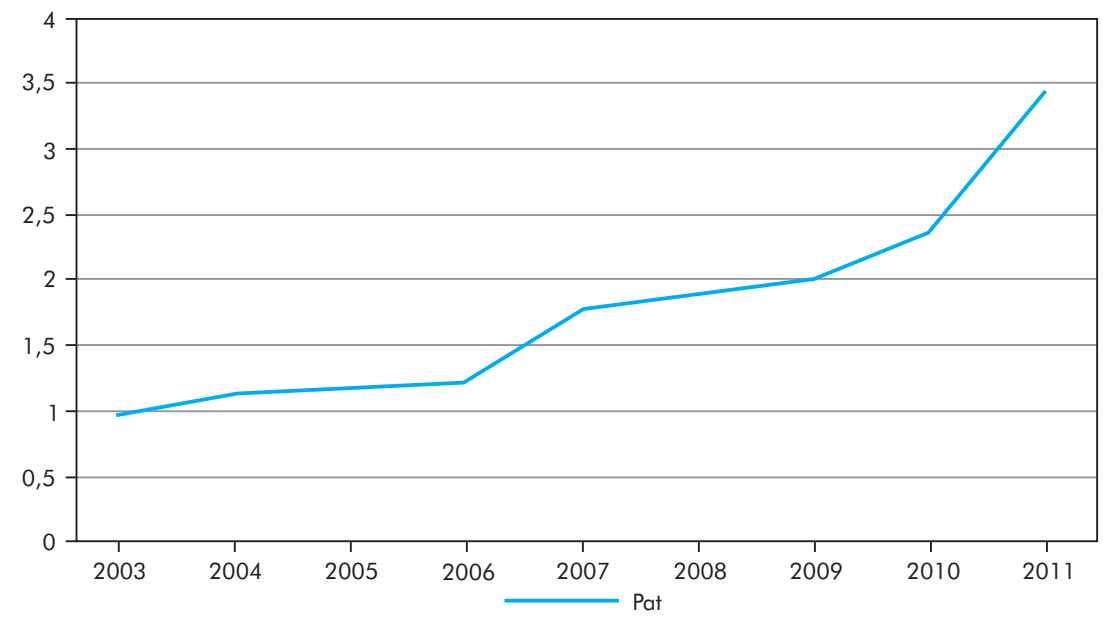

Source: Authors' own elaboration.

With regard to qualitative variables, one should note that in the period 578 observations had at least one program in the Exact area awarded for excellence, 35 of the 235 institutions in 2003, and 101 in 2011. In the Humanities area, this number was only 137 observations, 14 in 2003 and 17 in 2011. In the area of Biological Sciences, 105 observations had programs of excellence, 7 in 2003 and 15 in 2011. The average of high-quality research programs is low among the programs of Brazilian institutions. However, it is noteworthy that this number increased in the three areas in the period, especially in Exact and Land Sciences.

Table 1 - Description of variables used in the estimation, Brazil, 2003-2011

\begin{tabular}{lcccc}
\hline Variables & Average & Standard-Deviation & Minimun & Maximum \\
\hline PUB & $1,310.37$ & $3,726.83$ & 0 & 45,058 \\
PAT & 1.78 & 7.35 & 0 & 111 \\
STUDENTS & 8.63 & 1.77 & 0.00 & 11.68 \\
AGE & 36.97 & 25.48 & 1 & 217 \\
TKperPROF & $\mathrm{R} \$ 4,882.41$ & $\mathrm{R} \$ 12,487.50$ & $\mathrm{R} \$ 0.00$ & $\mathrm{R} \$ 110,852.90$ \\
\hline
\end{tabular}


Table 1 - Description of variables used in the estimation, Brazil, 2003-2011

(Cont.)

\begin{tabular}{|c|c|c|c|c|}
\hline Variables & Average & Standard-Deviation & Minimun & Maximum \\
\hline KRperPROF & $\mathrm{R} \$ 2,228.95$ & $\mathrm{R} \$ 15,718.76$ & $\mathrm{R} \$ 0.00$ & $\mathrm{R} \$ 383,801.10$ \\
\hline TKperSTUD & $\mathrm{R} \$ 602.57$ & $\mathrm{R} \$ 2,011.86$ & $\mathrm{R} \$ 0.00$ & $\mathrm{R} \$ 2,695.38$ \\
\hline KRperSTUD & $\mathrm{R} \$ 471.79$ & $\mathrm{R} \$ 5,535.66$ & $\mathrm{R} \$ 0.00$ & $\mathrm{R} \$ 147,773.70$ \\
\hline PROFperPOSTSTUD & 0.31 & 0.44 & 0 & 11 \\
\hline EXACT/LAND SC. & 3.44 & 12.72 & 0 & 68 \\
\hline HUMANITIES & 2.64 & 5.82 & 0 & 49 \\
\hline BIOLOGY & 2.23 & 8.10 & 0 & 102 \\
\hline MULTIDISCIPLINARY & 0.55 & 1.21 & 0 & 11 \\
\hline DQUALITY_EXA & 0.28 & 0.45 & 0 & 1 \\
\hline DQUALITY_HUM & 0.07 & 0.25 & 0 & 1 \\
\hline DQUALITY_BIO & 0.05 & 0.22 & 0 & 1 \\
\hline PUBLIC & 0.43 & 0.49 & 0 & 1 \\
\hline
\end{tabular}

Source: Authors' own elaboration.

\section{ECONOMETRIC RESULTS}

In this section we present the results for the model based on the Negative Binomial model with modified random effects (Tables 2 and 3). ${ }^{5}$ Four different specifications were used as the variable that investigates the effect of investments in scientific production, columns 1 to 4: in specification (1), the variable used was the total investment per member of the teaching staff (TKperPROF); in specification (2), total investment per student (TKperSTUD); in specification (3), investment in research aid per member of the teaching staff (KRperPROF); while in specification (4), investment in research aid per student (KRperSTUD).

Table 2 shows the determinants of the production of scientific knowledge by higher education and research institutions in Brazil. It controls the unobserved heterogeneity of these institutions, that is, characteristics inherent to them that are not observed, but that influence the number of publications. It is important to control unobserved effects since

5 The model's data with time-lagged independent variables are compatible with the results presented here and can be requested from the authors. In order to verify the existence of problems caused by multicollinearity in the regressions, the correlation matrix between the study variables was computed, see Table A3. 
institutional and cultural characteristics affect knowledge production in universities. When comparing the four specifications using the AIC and BIC information criteria, specification (1), in which the variable total investment per member of the teaching staff is added, has the lowest values and is chosen as the best fit.

The results show that the coefficient of the variable that measures the size of the higher education and research institution (STUDENTS) is positive and statistically significant at the level of significance of $1 \%$. In specification (1), for example, the increase of one point in the number of students in an institution would cause an increase in the record of expected publication counts by 0.23 units. This result is expected and in line with the international literature, in which it is argued that larger institutions find it easier to obtain financial resources for their research, both in the public and private spheres (CRESPI, 2007; DAVID, 2013; GURMU et al., 2010). In the Brazilian case, Morel and Morel (1978) confirmed that a larger research community is decisive in scientific production for the cases of universities in the states of Rio de Janeiro and São Paulo.

The coefficient of the variable of member of the teaching staff per postgraduation student (PROFperPOSTSTUD) is positive and equally significant for all confidence levels, with a coefficient of 0.14 . Thus, the result corroborates the literature (CORBUCCI, 2007; CRESPI, 2007), showing that the relative size of postgraduate programmes is a critical determinant of knowledge production. For example, Lyra and Guimarães (2007) claim that the strong growth of Brazilian scientific production abroad coincides with the expansion and strengthening of postgraduate programmes in the early 2000s. Caldarelli (2014) confirms that qualified teaching staff are a major factor in the capacity of institutions located in the state of Paraná to produce scientific knowledge.

The age of the higher education and research institution positively affects the production of knowledge in all specifications. The adding of one year to the age of the institutions increases the volume of publications by 0.32 units. Table A4 (Appendix) includes dummies of state-level funding agencies in the estimations and confirms this result, which reveals that older institutions have an advantage over newer ones in terms of publications, as in the case of the United Kingdom (CRESPI, 2007).

The set of variables corresponding to the number of postgraduate programs does not seem to affect, in the Exact area, or negatively affect, Humanities, Biology and Multidisciplinary fields, scientific production when measured in publications. The negative coefficient of programs in the biological area is a result that is contrary to some studies that focused on specific cases in Brazil (MEDEIROS and FARIA, 2006). These authors concluded that the courses and programs in this area are the most important for scientific production at UNESP. 
Table 2 - Determinants of scientific knowledge production in higher education and research institutions in Brazil, estimation by Negative Binomial Model, data panel, 2003-2011

\begin{tabular}{|c|c|c|c|c|}
\hline Dependent Variable: PUB & (1) & (2) & (3) & (4) \\
\hline Size of Institution (Students) & $\begin{array}{l}0.23^{* * *} \\
(0.04)\end{array}$ & $\begin{array}{l}0.24^{* * *} \\
(0.04)\end{array}$ & $\begin{array}{l}0.23^{* * *} \\
(0.04)\end{array}$ & $\begin{array}{l}0.24^{* * *} \\
(0.04)\end{array}$ \\
\hline Postgraduation (PROFperPOSTSTUD) & $\begin{array}{l}0.14^{* * *} \\
(0.03)\end{array}$ & $\begin{array}{l}0.15^{* * *} \\
(0.02)\end{array}$ & $\begin{array}{l}0.15^{\star * *} \\
(0.03)\end{array}$ & $\begin{array}{l}0.15^{* * *} \\
(0.02)\end{array}$ \\
\hline Age of Institution ( $A G E)$ & $\begin{array}{l}0.32^{* *} \\
(0.16)\end{array}$ & $\begin{array}{l}0.37^{\star *} \\
(0.15)\end{array}$ & $\begin{array}{l}0.35^{\star *} \\
(0.15)\end{array}$ & $\begin{array}{l}0.40^{* * *} \\
(0.15)\end{array}$ \\
\hline Postgraduate Program in Exact and Land Sc. & $\begin{array}{c}0.00 \\
(0.00)\end{array}$ & $\begin{array}{c}0.00 \\
(0.00)\end{array}$ & $\begin{array}{c}0.00 \\
(0.00)\end{array}$ & $\begin{array}{c}0.00 \\
(0.00)\end{array}$ \\
\hline Postgraduate Program in Humanities & $\begin{array}{c}-0.05^{* * *} \\
(0.02)\end{array}$ & $\begin{array}{l}-0.06^{* * *} \\
(0.02)\end{array}$ & $\begin{array}{l}-0.05^{* * *} \\
(0.02)\end{array}$ & $\begin{array}{c}-0.06^{* * *} \\
(0.02)\end{array}$ \\
\hline Postgraduate Program in Multidisciplinary & $\begin{array}{c}-0.11^{* * *} \\
(0.02)\end{array}$ & $\begin{array}{c}-0.13^{* * *} \\
(0.02)\end{array}$ & $\begin{array}{c}-0.12^{* * *} \\
(0.02)\end{array}$ & $\begin{array}{c}-0.13^{* * *} \\
(0.02)\end{array}$ \\
\hline Postgraduate Program in Biology & $\begin{array}{l}-0.05^{* *} \\
(0,02)\end{array}$ & $\begin{array}{c}-0.06^{* * *} \\
(0,02)\end{array}$ & $\begin{array}{l}-0.05^{* *} \\
(0,02)\end{array}$ & $\begin{array}{c}-0.06^{\star * *} \\
(0.02)\end{array}$ \\
\hline $\begin{array}{l}\text { Excellence in Exact and Land Sc. } \\
\left(D Q U A L I T Y \_E X A\right)\end{array}$ & $\begin{array}{l}0.71^{\star * *} \\
(0.06)\end{array}$ & $\begin{array}{c}0.74^{* * *} \\
(0.06)\end{array}$ & $\begin{array}{l}0.71^{\star * *} \\
(0.06)\end{array}$ & $\begin{array}{c}0.75^{\star * *} \\
(0.06)\end{array}$ \\
\hline $\begin{array}{l}\text { Excellence in Humanities (DQUALITY } \\
\text { HUM) }\end{array}$ & $\begin{array}{l}0.38^{* * *} \\
(0.09)\end{array}$ & $\begin{array}{c}0.36^{* * *} \\
(0.09)\end{array}$ & $\begin{array}{l}0.35^{* * *} \\
(0.09)\end{array}$ & $\begin{array}{c}0.35^{* * *} \\
(0.09)\end{array}$ \\
\hline Excellence in Biology (DQUALITY_BIO) & $\begin{array}{c}0.14 \\
(0,08)\end{array}$ & $\begin{array}{c}0.10 \\
(0,08)\end{array}$ & $\begin{array}{c}0.12 \\
(0,08)\end{array}$ & $\begin{array}{c}0.09 \\
(0,08)\end{array}$ \\
\hline PUBLIC & $\begin{array}{l}0.50^{* * *} \\
(0.09)\end{array}$ & $\begin{array}{c}0.51^{* * *} \\
(0.09)\end{array}$ & $\begin{array}{l}0.51^{* * *} \\
(0.09)\end{array}$ & $\begin{array}{c}0.48^{* * *} \\
(0.09)\end{array}$ \\
\hline $\begin{array}{l}\text { Total Investment per member of teaching } \\
\text { staff (TKperPROF) }\end{array}$ & $\begin{array}{c}0.14^{* * *} \\
(0.02)\end{array}$ & & & \\
\hline Total Investment per students (TKperSTUD) & & $\begin{array}{c}0.08^{* * *} \\
(0.03)\end{array}$ & & \\
\hline $\begin{array}{l}\text { Investment in research grants per member of } \\
\text { teaching staff (KRperPROF) }\end{array}$ & & & $\begin{array}{c}0.09^{* * *} \\
(0.02)\end{array}$ & \\
\hline $\begin{array}{l}\text { Investment in research grants per student } \\
(\text { KRperSTUD) }\end{array}$ & & & & $\begin{array}{c}0.02 \\
(0.03)\end{array}$ \\
\hline Constant & $\begin{array}{c}-2.74^{* * *} \\
(0.70)\end{array}$ & $\begin{array}{c}-2.91^{\star * *} \\
(0.68)\end{array}$ & $\begin{array}{c}-2.79^{* * *} \\
(0.69)\end{array}$ & $\begin{array}{c}-3.04^{* * *} \\
(0.67)\end{array}$ \\
\hline Dummies of Year & Yes & Yes & Yes & Yes \\
\hline Number of Observations & 2,044 & 2,044 & 2,044 & 2,044 \\
\hline Number of Institutions & 231 & 231 & 231 & 231 \\
\hline AIC & $23,341.75$ & $23,385.47$ & $23,366.79$ & $23,392.09$ \\
\hline $\mathrm{BIC}$ & $23,471.08$ & $23,514.80$ & $23,496.11$ & $23,521.41$ \\
\hline
\end{tabular}

Notes: Scientific production (dependent variable) includes articles in journals, book chapters, and complete works in \left. annals. Standard error in parentheses, being ${\left({ }^{* * *}\right)}^{*} p<0.01,\left(^{* *}\right) p<0.05,{ }^{*}\right) p<0.1$.

Source: Authors' own elaboration. 
Regarding the relationship between excellence postgraduate programs and scientific knowledge production, a positive and significant impact was found for the Exact and Land Sciences (DQUALITY_EXA) and Humanities (DQUALITY_HUM) programs. The DQUALITY_EXA variable presents coefficients with higher values than the other fields, which may reflect the fact that in Brazil the number of programs of excellence in this area are larger. An explanation could be that better quality postgraduate courses have better prepared and more qualified students who produce more publications. Glanzel and Schubert (2003) point out that the fields of Agriculture and Earth and Space Sciences were the most active in the production of publications, based on the Web of Science records. Leta et al. (2013) arrived to a similar conclusion, finding Physics to be a field of growing and important scientific production for the Brazilian knowledge stock, a trend that had already been observed by Morel and Morel (1978).

The variable that distinguishes public and private institutions (PUBLIC) is statistically and positively related to the production of basic research in universities. In the Brazilian case, public higher education and research institutions are more productive than private ones, corroborating the arguments by Martins (2002) that public universities in Brazil, especially the federal ones, have become a place for discussion and dissemination of scientific themes. Chiarini and Vieira (2012) also confirmed the contribution of universities financed by the Brazilian government to the level of national and international publications. According to Maculan and Mello (2009), basic and applied research activities by private institutions in Brazil are almost entirely residual, with teaching being its main objective. Caldarelli et al. (2014) used a similar argument to explain the low participation of private institutions state scientific production in the state of Paraná.

The variables of public investments carried out in higher education and research institutions (TKperPROF, TKperSTUD, KRperPROF) are significant determinants for scientific production. They present positive and highly significant coefficients for the specifications, corroborating what has been found by more than one scientific work in the literature. The variable that has the highest value among the coefficients is the total investment per member of teaching staff (column 1), a specification with the best fit according to the AIC and BIC criteria. The importance of public investment variables is evidenced by works such as Whalley and Hicks (2013), David (2013) and Abigail and Siow (2003), for North American institutions, and Crespi (2007) for British institutions. In the Brazilian case, Leta, Thijs and Glanzel (2013) argue that the evolution of Brazilian scientific production observed in the years 2007-2010 in world participation was due to the continuous public investment in institutions.

Table 3 contains the estimates for university technological production (PAT), measured through patent applications. In these estimations, some changes have been 
made in the econometric specification when compared to Table 2, referring to scientific production. In particular, the variables related to the programs in the Humanities (Humanities and DQUALITY_HUM) have been removed in view of the fact that the generation of patents occurs more commonly in other areas of knowledge, such as Exact Sciences and Biology fields, which are more focused on technological production. Analyzing the AIC and BIC criteria, it is concluded that specification 2 is the one with the best fit, that is, the one that uses total investment per student.

After controlling for the individual characteristics of Brazilian higher education and research institutions, it is observed that the variables such as member of the teaching staff per postgraduate students (PROFperPOSTSTUD), existence of programs of excellence in Biology (Biology and DQUALITY_BIO) do not have statistical significance, that is, they do not seem to affect the number of patent applications.

In particular, the results indicate that the number of university patent applications is positively and highly influenced by the size of the institution, variable Students. As seen for scientific production, larger institutions are better able to create patentable knowledge because they have more resources to be allocated in the development of these outputs. Similar results have been found in the international literature by Gurmu et al. (2010), Hewitt-Dundas (2012), Bulut and Moschini (2009), and Coupé (2003).

The other variables showed coefficients consistent with the literature. The age of institutions had a positive and significant sign. The list of older institutions and the creation of university patents was addressed by Crespi (2007), who reached similar conclusions.

\section{Table 3 - Determinants of technological knowledge production in higher education and research institutions in Brazil, estimation through Negative Binomial Model, panel data, 2003-2011}

\begin{tabular}{lcccc}
\hline Dependent Variable: PAT & $(1)$ & $(2)$ & $(3)$ & $(4)$ \\
\hline Size of Institution (Students) & $0.47^{* * *}$ & $0.48^{* * *}$ & $0.47^{* * *}$ & $0.47^{* * *}$ \\
& $(0.10)$ & $(0.10)$ & $(0.10)$ & $(0.10)$ \\
Postgraduation & 0.20 & 0.22 & 0.21 & 0.25 \\
(PROFperPOSTSTUD) & $(0.17)$ & $(0.17)$ & $(0.17)$ & $(0.17)$ \\
& $0.93^{* *}$ & $0.96^{* *}$ & $0.90^{* *}$ & $0.89^{* *}$ \\
Age of Institution (AGE) & $(0.43)$ & $(0.43)$ & $(0.42)$ & $(0.43)$ \\
& $0.01^{* * *}$ & $0.01^{* * *}$ & $0.01^{* * *}$ & $0.01^{* * *}$ \\
$\begin{array}{l}\text { Postgraduate Program in Exact and } \\
\text { Land Sc. }\end{array}$ & $(0.00)$ & $(0.00)$ & $(0.00)$ & $(0.00)$ \\
Postgraduate Program in & $-0.06^{* *}$ & $-0.06^{* *}$ & $-0.07^{* *}$ & $-0.07^{* * *}$ \\
Multidisciplinary & $(0.03)$ & $(0.03)$ & $(0.03)$ & $(0.03)$ \\
\hline
\end{tabular}


Table 3 - Determinants of technological knowledge production in higher education and research institutions in Brazil, estimation through Negative Binomial Model, panel data, 2003-2011

\begin{tabular}{|c|c|c|c|c|}
\hline Dependent Variable: $P A T$ & (1) & (2) & (3) & (4) \\
\hline \multirow{2}{*}{ Postgraduate Program in Biology } & 0.04 & 0.03 & 0.04 & 0.04 \\
\hline & $(0.03)$ & $(0.03)$ & $(0.03)$ & $(0.03)$ \\
\hline \multirow{2}{*}{$\begin{array}{l}\text { Excellence in Exact and Land } S c \text {. } \\
\left(D Q U A L I T Y \_E X A\right)\end{array}$} & $0.22^{*}$ & 0.22 & $0.23^{*}$ & $0.23^{*}$ \\
\hline & $(0.14)$ & $(0.14)$ & $(0.13)$ & $(0.13)$ \\
\hline \multirow{2}{*}{$\begin{array}{l}\text { Excellence in Humanities } \\
\text { (DQUALITY_HUM) }\end{array}$} & 0.06 & 0.06 & 0.07 & 0.08 \\
\hline & $(0.13)$ & $(0.13)$ & $(0.13)$ & $(0.13)$ \\
\hline \multirow{2}{*}{ Public } & $2.83^{* * *}$ & $2.82^{* * *}$ & $2.83^{* * *}$ & $2.80^{* * *}$ \\
\hline & $(0.27)$ & $(0.27)$ & $(0.27)$ & $(0.27)$ \\
\hline \multirow{2}{*}{$\begin{array}{l}\text { Total Investiment per member of the } \\
\text { teaching staff (TKperPROF) }\end{array}$} & $0.14^{*}$ & & & \\
\hline & $(0.08)$ & & & \\
\hline \multirow{2}{*}{$\begin{array}{l}\text { Total Investment per students } \\
(\text { TKperSTUD) }\end{array}$} & & $0.34^{\star * *}$ & & \\
\hline & & $(0.11)$ & & \\
\hline \multirow{2}{*}{$\begin{array}{l}\text { Investment in research grants per } \\
\text { member of the teaching staff } \\
(\text { KRperPROF })\end{array}$} & & & $0.11^{*}$ & \\
\hline & & & $(0.06)$ & \\
\hline \multirow{2}{*}{$\begin{array}{l}\text { Investment in research grants per } \\
\text { student (KRperSTUD) }\end{array}$} & & & & $0.25^{\star * *}$ \\
\hline & & & & $(0.09)$ \\
\hline \multirow{2}{*}{ Constant } & $-8.93^{* * *}$ & $-9.25^{* * *}$ & $-8.83^{* * *}$ & $-8.94^{* * *}$ \\
\hline & $(1.91)$ & $(1.95)$ & $(1.90)$ & $(1.91)$ \\
\hline Dummies of Year & Yes & Yes & Yes & Yes \\
\hline Number of Observations & 2,044 & 2,044 & 2,044 & 2,044 \\
\hline Number of Institutions & 231 & 231 & 231 & 231 \\
\hline AIC & $3,100.49$ & $3,093.47$ & $3,101.05$ & $3,095.98$ \\
\hline $\mathrm{BIC}$ & $3,218.57$ & $3,211.55$ & $3,219.12$ & $3,214.06$ \\
\hline
\end{tabular}

Note: Standard error in parentheses, being $\left({ }^{* * *}\right) p<0.01,\left({ }^{* *}\right) p<0.05$, and $\left({ }^{*}\right) p<0$.

Source: Authors' own elaboration.

The variables of postgraduate programs in the Exact field (Exact and Land Sc. and DQUALITY_EXA) positively affect the production of patents, that is, they influence technological production in Brazilian universities. This result is in line with the literature that relates a highly qualified technical staff (teaching staff and postgraduate students) to the generation of applied knowledge (SORIA et al., 2010). Compared to the hard sciences in the article by David (2013), that area has a positive and significant impact on the production of research at the best and most prestigious North American universities. Amadei and Torkomian (2009) defend the importance of postgraduate programs for the production of technological knowledge at universities in the state of São Paulo. According to them, this level of education would be the backbone of 
scientific research. The more members of teaching staff with $\mathrm{PhDs}$ and postgraduate students, the greater the production of applied research by institutions (GURMU et al., 2010), as these are professionals engaged in frontier scientific research.

The variable that indicates whether an institution is public presented positive and significant coefficients in all specifications, indicating that institutions of this nature tend to patent more the knowledge created within its walls than private ones. Amadei and Torkomian (2009) confirm this predominance of public universities in São Paulo in the production of patent deposits over private ones.

The results indicate that the number of university patent applications is positively related to investment, regardless of whether the investment variable is included as total investment (TKperPROF and TKperSTUD) or investment in research grants (KRperPROF and KRperSTUD). The highest coefficient among the investment variables is the total investment per student (TKperSTUD), a specification pointed out as the best based on the criteria of AIC and BIC. In international experience, there is evidence that university investment or federal spending on research are positively associated with technological production (GURMU et al., 2010; FISCH et al., 2015; ABIGAIL and SIOW, 2003).

\section{CONCLUSIONS}

This article evaluated the drivers of scientific and technological production of Brazilian higher education and research institutions in the period 2003-2011.

First, the size of higher education institutions, taking the proportion of undergraduate students as a proxy, is a crucial determinant of scientific production, measured as articles in periodicals, books, and complete works published in annals in Brazil. This conclusion is understandable since the largest Brazilian educational institutions, in general, have better infrastructure, in addition to more human resources employed in the production of scientific publications.

Second, another driver for the production of the two university outputs analyzed is the number of teaching staff per postgraduate student. The availability of more human resources of this type is a precondition for scientific and technological production in universities.

Third, the quality of stricto-sensu postgraduate programs, that is, the existence of Exact and Land Sciences, Humanities, and Biology programs best evaluated by Capes, has a positive association with scientific production. However, no statistical association has been found with the number of graduate programs. In the case of technological production, the conditions are different. There is a positive association between the number of programs in Exact and Land Sciences and the number of patents issued, 
although no association has been found between the number of patents and the excellence of Exatas programs. The result suggests a potential preponderance of scientific production over technology, a feature of the Brazilian national innovation system.

Fourth, there is a strong statistical relationship between publications and patents, on the one hand, and investment in teaching staff or students, on the other. This finding shows the importance of investment in university outputs, confirming that $\mathrm{CNPq}$ resources have been well allocated.

Based on the results, public policies can be suggested to strengthen the Brazilian university system, especially the public ones. Expanding the support for basic science is paramount, since it only takes place in public institutions and because it has possible interrelationships with applications in the production system. It is also necessary to focus on mechanisms for converting knowledge applied to products and services in the business sector. In this respect, improving university-business interaction mechanisms can contribute to reducing the gap between scientific and technological production and the absorption of its outputs by the business sectors.

In terms of possible directions for future research, it is necessary to consider other ways of measuring the product of educational and research institutions, as this article is limited to considering the production of articles in periodicals, books and conference proceedings, in addition to patents. A second avenue of research is linked to the position of institutions in the networks of scientific and technological production. A third step forward would be to consider factors that measure the quality of publications, such as article citations or the weighting of the publication by the journal's impact factor.

\section{REFERENCES}

ABIGAIL, P. A.; SIOW, A. Does federal research funding increase university research output? The B.E. Journal of Economic Analysis \& Policy, v. 3, n. 1, p. 1-24, 2003.

ALBUQUERQUE, E. M. Sistema nacional de inovação no Brasil: uma análise introdutória a partir de dados disponíveis sobre a ciência e a tecnologia. Revista de Economia Politica, v. 16, n. 3, 1996.

ALLISON, P. D.; WATERMAN, R. P. Fixed-effects negative binomial regression models. Sociological Methodology, v. 32, p. 247-265, 2002.

AMADEI, J. R. P.; TORKOMIAN, A. L. V. As patentes nas universidades: análise dos depósitos das universidades públicas paulistas. Ciência da Informação, v. 38, n. 2, p. 9-18, 2009.

BEKHRADNIA, B. Diverse challenges, diverse solutions. In: IACOBUCCI, F.; TUOHY, C. (Eds.) Taking public universities seriously. Toronto: University of Toronto Press, 2004, p. 38-43.

BOLLI, T.; SOMOGYI, F. Do competitively acquired funds induce universities to increase productivity? Research Policy, n. 40, p. 136-147, 2011. 
BULUT, H.; MOSCHINI, G. US universities' net returns from patenting and licensing: A quantile regression analysis. Economics of Innovation and New Technology, v. 18, p. 123-37, 2009.

BRAMWELL, A.; WOLFE, D. A. Universities and regional economic development: The entrepreneurial University of Waterloo. Research Policy, v. 37, p. 1175-1187, 2008.

CALDARELLI, C. E. et al. Análise de indicadores de produção científica e geração de conhecimento nas universidades estaduais paranaenses. Teoria e Evidência Econômica, v. 20, n. 43, p. 313-36, 2014.

CAPES - COORDENAÇÃO DE APERFEIÇOAMENTO DE PESSOAL DE NÍVEL SUPERIOR. Dados sobre produção científica, notas dos cursos e alunos de pós-graduação. Brasília: CAPES, 2015. Available at: http://www.capes.gov.br/. Acesso em: 12 mar. 2015.

CASTRO, B. S.; SOUZA, G. C. O papel dos Núcleos de Inovação Tecnológica. Liinc em Revista, v. 8, n. 1, p. 125-140, mar. 2012.

CHAIMOVICH, H. Brasil, ciência, tecnologia: alguns dilemas e desafios. Estudos Avançados, São Paulo, v. 14, n. 40, p.134-143, set./dez. 2000.

CHIARINI, T.; VIEIRA, K. P. Universidades como produtoras de conhecimento para o desenvolvimento económico: sistema superior de ensino e as políticas de CT\&I. Revista Brasileira de Educação, v. 66, n. 1, p. 117-32, 2012.

COSTA, E. M. et al. Dinâmica da eficiência produtiva das instituições Federais de ensino superior. Planejamento e Políticas Públicas, n. 44, jan./jun. 2015.

COUPÉ, T. Science is golden: academic R\&D and university patents. Journal of Technology Transfer, v. 15, n. 28, p. 31-46, 2003.

CRESPI, G. The UK knowledge production function. In: BONACCORSI, A.; DARAIO, C. (Eda.) Universities and strategic knowledge creation: specialization and performance in Europe. UK: Cheltenham, 2007, p. 306-339.

DAVID, Q. The determinants of research production at top US universities. The B.E. Journal of Economic Analysis \& Policy, v. 14, n. 1, p. 81-109, 2013.

ETZKOWITZ, H. et al. The future of the university and the university of the future: Evolution of ivory tower to entrepreneurial paradigm. Research Policy, v. 29, p. 313-330, 2000.

ETZKOWITZ, H.; LEYDESDORFF, L. The dynamics of innovation: from national systems and model 2 to a triple helix of universityindustry-government relations. Research Policy, n. 29, p. 109-123, Feb. 2000.

ETZKOWITZ, H.; LEYDESDORFF, L. Universities and the global knowledge economy: a triple helix of university-industry-government relations. London: Cassell Academic, 1997.

FAÇANHA, L.; MARINHO, A. Instituições federais de ensino superior: modelos de financiamento e o incentivo à eficiência. Revista Brasileira de Economia, v. 53, n. 3, p. $357-$ 386, 1999.

FAÇANHA, L.; MARINHO, A. Instituições de ensino superior governamentais e particulares: avaliação comparative de eficiência. Revista de Administração Pública, v. 35, n. 6, p. 83-105, 2001.

FIGUEIREDO, V. O sistema de C\&T no Brasil: institucionalização e desafios. Cadernos de Ciência \& Tecnologia, v. 15, n. 2, p. 7-25, mai./ago. 1998. 
FISCH, C. O. et al. University patenting: a comparison of 300 leading universities worldwide. Journal of Technological Transfer, v. 40, n. 2, p. 318-45, 2015.

GARCIA, R. et al. How the benefits, results and barriers of collaboration affect university engagement with industry. Science and Public Policy, v. 46, p. 347-357, jun. 2019.

GODIN, B.; GINGRAS, Y. Impact of collaborative research on academic science. Science and Public Policy, v. 27, n. 1, p. 65-73, 2000.

GONÇALVES, E.; CÓSER, I. O Programa de Incentivo à Inovação como mecanismo de fomento ao empreendedorismo acadêmico: a experiência da UFJF. Nova Economia, v. 24, p. 555-596, 2014.

GLÄNZEL, W.; SCHUBERT, A. A new classification scheme of science fields and subfields designed for scientometric evaluation purposes. Scientometrics, v. 56, n. 3, p. 357-67, 2003.

GREGOLIN, J. A. R. Análise da produção científica a partir de indicadores bibliométricos. In: FAPESP - FUNDAÇÃO DE AMPARO À PESQUISA DO ESTADO DE SÃO PAULO. Indicadores de ciência, tecnologia e inovação em São Paulo. São Paulo: FAPESP, 2005.

GRILICHES, Z. Issues in assessing the contribution of research and development to productivity growth. Bell Journal of Economics, v. 10, p. 92-116, 1979.

GURMU, S. et al. The knowledge production function for university patenting. Economic Inquiry, p. 192-213, 2010.

HAUSMAN, J.; HALL, B. H.; GRILICHES, Z. Econometric models for count data with an application to the patents-R\&D relationship. Econometrica, v. 52, p. 909-938, 1984.

HEWITT-DUNDAS, N. Research intensity and knowledge transfer activity in UK universities. Research Policy, v. 41, p. 262-75, 2012.

INPI - INSTITUTO NACIONAL DA PROPRIEDADE INDUSTRIAL. Dados sobre patentes em instituições de ensino e pesquisa. Rio de Janeiro: INPI, 2015. Available at: http://www.inpi. gov.br/. Acesso em: 19 mar. 2015.

INEP - INSTITUTO NACIONAL DE ESTUDOS E PESQUISAS EDUCACIONAIS ANÍSIO TEIXEIRA. Investimentos em educação. Brasília: INPE, 2015. Available at: http://www.inep. gov.br/superior/censosuperior/sinopse/default.asp. Acesso em 14 mar. 2015.

LANDRY, R.; AMARA, N.; OUIMET, M. Determinants of knowledge transfer: evidence from Canadian university researchers in natural sciences and engineering. Journal of Technology Transfer, v. 32, p. 561-592, 2006.

LETA, J.; CRUZ, C. H. B. A produção científica brasileira. In: VIOTTI, E. B.; MACEDO, M. M. (Orgs.) Indicadores de ciência, tecnologia e inovação no Brasil. Campinas: Ed. da UNICAMP, 2003.

LETA, J.; THIJBS, B.; GLANZEL, W. A macro-level study of science in Brazil: seven years later. Encontros Bibli, v. 18, n. 36, 2013.

LYRA, T. M. P.; GUIMARÃES, J. A. Produção científica brasileira em comparação com o desempenho mundial em ciencia agrícolas. Pesquisa e Planejamento Econômico, v. 32, n. 30, 2007.

MACULAN, A. M.; MELLO, J. M. C. University start-ups for breaking lock-ins of the Brazilian economy. Science and Public Policy, v. 36, p. 109-14, 2009. 
MARTINS, C. B. A formação do sistema nacional da pós-graduação. In: SOARES, M. S. A. (Coord.) A educação superior no Brasil. Brasília: CAPES, 2002.

MEDEIROS, A. P. S. C.; FARIA, L. I. L. Análise bibliométrica da produção científica da UNESP. In: SNBU - SEMINÁRIO NACIONAL DE BIBLIOTECAS UNIVERSITÁRIAS, Salvador, BA, 2006.

MENEGHINI, R. Produção científica. In: FAPESP - FUNDAÇÃO DE AMPARO À PESQUISA DO ESTADO DE SÃO PAULO. Indicadores de ciência, tecnologia e inovação em São Paulo. São Paulo: FAPESP, 2001, p. 1-22. Disponível em: http://www.fapesp.br/indct/cap06/cap06.htm.

MOREL, R. L. M.; MOREI, C. M. Um estudo sobre a produção científica brasileira, segundo os dados do Institute for Scientific Information (ISI). Ciência da Informação, v. 6, n. 2, p. 99 109, 1977.

MOWERY, D. C.; SAMPAT, B. N. Universities in national innovation systems. In: FAGERBERG, J.; MOWERY, D. C.; NELSON, R. R. (Eds.) The Oxford Handbook of Innovation. New York: Oxford University Press.

NELSON, R; WINTER, S. G. Uma teoria evolucionária da mudança econômica. Campinas: Ed. da Unicamp, 2005. (Clássicos da Inovação)

NELSON, R. R. A Retrospective. In: NELSON, R. R. (Ed.) National Innovation Systems: a comparative analysis. New York, Oxford: Oxford University Press, 1993, p. 505-523.

NEVES, C. E. B. Ciência e Tecnologia no Brasil. In: SOARES, M. S. A. (Coord.) A Educação Superior no Brasil. Brasília: CAPES, 2002.

PÓVOA, L. M. C.; RAPINI, M. S. Technology transfer from universities and public research institutes to firms in Brazil: what is transferred and how the transfer is carried out. Science and Public Policy, v. 37, n. 2, p. 147-159, mar. 2010.

RAPINI, M. S.; CAMPOS, B. C. As universidades mineiras e suas interações com a indústria: uma análise a partir de dados do Diretório. In: SEMINÁRIO SOBRE A ECONOMIA MINEIRA, 11, Diamantina, MG, 2004.

RAPINI, M. S.; CHIARINI, T.; BITTENCOURT, P. F. University-firm interactions in Brazil: Beyond human resources and training missions. Industry \& Higher Education, v. 29, p. 111127, 2015.

ROSENBERG, N. Why do firms do basic research (with their own money)? Research Policy, v. 19, p. 165-174, 1990.

SORIA, A. F. et al. Geração de patentes em universidades: um estudo exploratório. Revista de Administração Faces Journal, v. 9, n. 3, p. 95-116, 2013.

STOKES, D. E. O quadrante de Pasteur: a ciência básica e a inovação tecnológica. Campinas: Ed. da Unicamp, 2005. (Coleção Clássicos da Inovação)

TARGINO, M. G.; CALDEIRA, P. T. Análise da produção científica em uma instituição de ensino superior: o caso da Universidade Federal do Piauí. Ciência da Informação, v. 17, n. 1, p. 15-25, 1988.

WHALLEY, A.; HICKS, J. Spending wisely? How resources affect knowledge production in universities. Economic Inquiry, v. 52, v. 1, p. 35-55, 2013.

WOOLDRIDGE, J. M. Introdução à econometria: uma abordagem moderna. São Paulo: Thomson Learning, 2006. 


\section{APPENDIX}

Table A1 - Description of dependente variable: PUB (scientific production)

\begin{tabular}{lccc}
\hline Percentile & \multicolumn{3}{l}{} \\
\hline $1 \%$ & 0 & Average & 1309.77 \\
$5 \%$ & 0 & Standard-Deviation & 3726.04 \\
$10 \%$ & 0 & Variance & $1.39 \mathrm{E}+07$ \\
$25 \%$ & 0 & Skewness & 7.13 \\
$50 \%$ & 213.5 & Curtosis & 69.74 \\
$75 \%$ & 878 & $\mathrm{~N}$ & 2,082 \\
$90 \%$ & 3,503 & & \\
$95 \%$ & 6,219 & & \\
$99 \%$ & 14,809 & & \\
\hline
\end{tabular}

Note: Scientific production includes articles in journals; book chapters; and complete works in annals.

Source: Authors' own elaboration.

Table A2 - Description of depedent variable: PAT (patent applications)

\begin{tabular}{llcc}
\hline Percentile & & & \\
\hline $1 \%$ & 0 & Average & 1.78 \\
$5 \%$ & 0 & Standard-Deviation & 7.35 \\
$10 \%$ & 0 & Variance & 53.96 \\
$25 \%$ & 0 & Skewness & 7.72 \\
$50 \%$ & 0 & Curtosis & 77.79 \\
$75 \%$ & 0 & $\mathrm{~N}$ & 2,082 \\
$90 \%$ & 4 & & \\
$95 \%$ & 9 & & \\
\hline
\end{tabular}

Source: Authors' own elaboration. 
Table A3 - Correlation matrix for variables used in econometric regressions

\begin{tabular}{|c|c|c|c|c|c|c|c|c|c|c|c|c|c|c|c|}
\hline & (1) & (2) & (3) & (4) & (5) & (6) & (7) & (8) & (9) & (10) & (11) & (12) & (13) & (14) & (15) \\
\hline (1) & 1.00 & & & & & & & & & & & & & & \\
\hline (2) & 0.02 & 1.00 & & & & & & & & & & & & & \\
\hline (3) & -0.00 & 0.17 & 1.00 & & & & & & & & & & & & \\
\hline (4) & 0.01 & 0.01 & 0.14 & 1.00 & & & & & & & & & & & \\
\hline (5) & -0.02 & 0.05 & 0.50 & 0.09 & 1.00 & & & & & & & & & & \\
\hline (6) & -0.00 & 0.06 & 0.42 & 0.08 & 0.48 & 1.00 & & & & & & & & & \\
\hline (7) & -0.00 & 0.06 & 0.37 & 0.08 & 0.46 & 0.37 & 1.00 & & & & & & & & \\
\hline (8) & 0.19 & 0.08 & 0.20 & 0.02 & 0.14 & 0.29 & 0.14 & 1.00 & & & & & & & \\
\hline (9) & 0.27 & 0.00 & 0.02 & 0.00 & 0.05 & 0.03 & 0.00 & 0.31 & 1.00 & & & & & & \\
\hline (10) & 0.20 & 0.00 & 0.07 & 0.02 & 0.10 & 0.09 & 0.10 & 0.31 & 0.61 & 1.00 & & & & & \\
\hline (11) & -0.01 & 0.00 & 0.00 & 0.00 & 0.00 & 0.00 & 0.00 & 0.29 & 0.18 & 0.26 & 1.00 & & & & \\
\hline (12) & 0.01 & 0.19 & 0.72 & 0.08 & 0.27 & 0.24 & 0.22 & 0.15 & 0.01 & 0.03 & 0.00 & 1.00 & & & \\
\hline (13) & -0.02 & 0.14 & 0.73 & 0.11 & 0.34 & 0.29 & 0.27 & 0.16 & 0.02 & 0.04 & 00 & 0.91 & 1.00 & & \\
\hline (14) & 0.00 & 0.16 & 0.73 & 0.09 & 0.30 & 0.27 & 0.23 & $0 ., 15$ & 0.02 & 0.03 & 0.00 & 0.89 & 0.87 & 1.00 & \\
\hline (15) & -0.02 & 0.10 & 0.69 & 0.12 & 0.37 & $0 ., 33$ & 0.26 & 0.16 & 0.03 & 0.05 & 0.00 & 0.78 & 0.89 & 0.89 & 1.00 \\
\hline
\end{tabular}

Table A4 - Determinants of scientific knowledge production in higher education and research institutions in Brazil, estimation through Negative Binomnial Model, Panel Data, 2003-2011

\begin{tabular}{lcccc}
\hline Dependent Variable: PUB & $(\mathbf{1})$ & $(2)$ & $(3)$ & $(\mathbf{4})$ \\
\hline Size of Institution (Students) & $0.27^{* * *}$ & $0.28^{* * *}$ & $0.27^{* * *}$ & $0.30^{* * *}$ \\
& $(0.04)$ & $(0.04)$ & $(0.04)$ & $(0.04)$ \\
Postgraduation (PROFperPOSTSTUD) & $0.15^{* * *}$ & $0.16^{* * *}$ & $0.16^{* * *}$ & $0.15^{* * *}$ \\
Age of Institution (AGE) & $(0.02)$ & $(0.02)$ & $(0.02)$ & $(0.02)$ \\
& $0.55^{* * *}$ & $0.54^{* * *}$ & $0.56^{* * *}$ & $0.56^{* * *}$ \\
Postgraduate Program in Exact and & $(0.15)$ & $(0.14)$ & $(0.15)$ & $(0.14)$ \\
Land Sc. & 0.00 & 0.00 & 0.00 & 0.00 \\
& $(0.01)$ & $(0.01)$ & $(0.01)$ & $(0.01)$ \\
Postgraduate Program in Humanities & $-0.03^{* *}$ & $-0.04^{* * *}$ & $-0.04^{* * *}$ & $-0.04^{* * *}$ \\
Postgraduate Program in & $(0.01)$ & $(0.01)$ & $(0.01)$ & $(0.01)$ \\
Multidisciplinary & $-0.08^{* * *}$ & $-0.09^{* * *}$ & $-0.09^{* * *}$ & $-0.09^{* * *}$ \\
Postgraduate Program in Biology & $(0.01)$ & $(0.01)$ & $(0.01)$ & $(0.01)$ \\
Excellence in Exact and Land Sc. & $-0.04^{* *}$ & $-0.04^{* *}$ & $-0.04^{* *}$ & $-0.04^{* *}$ \\
(DQUALITY_EXA) & $(0.02)$ & $(0.02)$ & $(0.02)$ & $(0.02)$ \\
\hline
\end{tabular}


Table A4 - Determinants of scientific knowledge production in higher education and research institutions in Brazil, estimation through Negative Binomnial Model, Panel Data, 2003-2011

\begin{tabular}{|c|c|c|c|c|}
\hline Dependent Variable: PUB & (1) & (2) & (3) & (4) \\
\hline \multirow{2}{*}{$\begin{array}{l}\text { Excellence in Humanities (DQUALITY } \\
\text { HUM) }\end{array}$} & $0.32^{* * *}$ & $0.31^{\star * \star}$ & $0.29^{* * *}$ & $0.31^{* * *}$ \\
\hline & $(0.08)$ & $(0.08)$ & $(0.08)$ & $(0.08)$ \\
\hline \multirow{2}{*}{$\begin{array}{l}\text { Excellence in Biology (DQUALITY } \\
\text { BIO) }\end{array}$} & 0.00 & -0.03 & -0.01 & -0.04 \\
\hline & $(0.07)$ & $(0.07)$ & $(0.07)$ & $(0.07)$ \\
\hline \multirow{2}{*}{ PUBLIC } & $1.19^{* * *}$ & $1.17^{\star * *}$ & $1.18^{* * *}$ & $1.11^{* * *}$ \\
\hline & $(0.11)$ & $(0.11)$ & $(0.11)$ & $(0.11)$ \\
\hline \multirow{2}{*}{$\begin{array}{l}\text { Total Investiments per member of the } \\
\text { teaching staff (TKperPROF) }\end{array}$} & $0.13^{* * *}$ & & & \\
\hline & $(0.02)$ & & & \\
\hline \multirow{2}{*}{$\begin{array}{l}\text { Total Investiments per students } \\
\text { (TKperSTUD) }\end{array}$} & & $0.06^{* *}$ & & \\
\hline & & $(0.03)$ & & \\
\hline \multirow{2}{*}{$\begin{array}{l}\text { Investiments in research grants per } \\
\text { member of the teaching staff } \\
(\text { KRperPROF) }\end{array}$} & & & $0.07^{* * *}$ & \\
\hline & & & $(0.02)$ & \\
\hline \multirow{2}{*}{$\begin{array}{l}\text { Investiments in research grants per } \\
\text { student (KRperSTUD) }\end{array}$} & & & & -0.00 \\
\hline & & & & $(0.02)$ \\
\hline \multirow{2}{*}{ Dummy of Year (2003) } & $3.64^{* * *}$ & $3.30^{* * *}$ & $3.58^{* * *}$ & $3.31^{* * *}$ \\
\hline & $(1.16)$ & $(1.13)$ & $(1.16)$ & $(1.12)$ \\
\hline \multirow{2}{*}{ Dummy of Year (2004) } & $3.05^{* * *}$ & $2.76^{* * *}$ & $3.02^{* * *}$ & $2.78^{* * *}$ \\
\hline & $(1.02)$ & $(0.99)$ & $(1.02)$ & $(0.98)$ \\
\hline \multirow{2}{*}{ Dummy of Year (2005) } & $2.69^{* * *}$ & $2.46^{\star * *}$ & $2.67^{* * *}$ & $2.47^{* * *}$ \\
\hline & $(0.87)$ & $(0.85)$ & $(0.87)$ & $(0,84)$ \\
\hline \multirow{2}{*}{ Dummy of Year (2006) } & $2.27^{* * *}$ & $2.09^{* * *}$ & $2.26^{* * *}$ & $2.11^{* * *}$ \\
\hline & $(0.73)$ & $(0.71)$ & $(0.73)$ & $(0.70)$ \\
\hline \multirow{2}{*}{ Dummy of Year (2007) } & $1.85^{* * *}$ & $1.72^{* * *}$ & $1.85^{* * *}$ & $1.75^{* * *}$ \\
\hline & $(0.58)$ & $(0.57)$ & $(0.58)$ & $(0.56)$ \\
\hline \multirow{2}{*}{ Dummy of Year (2008) } & $1.32^{\star * *}$ & $1.22^{\star * *}$ & $1.32^{\star * *}$ & $1.24^{* * *}$ \\
\hline & $(0.44)$ & $(0.43)$ & $(0.44)$ & $(0.42)$ \\
\hline \multirow{2}{*}{ Dummy of Year (2009) } & $0.87^{* * *}$ & $0.80^{* * *}$ & $0.86^{* * *}$ & $0.82^{* * *}$ \\
\hline & $(0.29)$ & $(0.29)$ & $(0.29)$ & $(0.28)$ \\
\hline \multirow{2}{*}{ Dummy of Year (2010) } & $0.41^{* * *}$ & $0.39^{* * *}$ & $0.41^{* * *}$ & $0.40^{* * *}$ \\
\hline & $(0.15)$ & $(0.15)$ & $(0.15)$ & $(0.15)$ \\
\hline \multirow{2}{*}{ Constant } & $-4.94^{\star * *}$ & $-4.94^{* * *}$ & $-4.99^{* * *}$ & $-5.08^{* * *}$ \\
\hline & $(0.72)$ & $(0.70)$ & $(0.71)$ & $(0.69)$ \\
\hline $\begin{array}{l}\text { Dummies for Research Funding } \\
\text { Foundation }\end{array}$ & Yes & Yes & Yes & Yes \\
\hline Number of Observations & 2,044 & 2,044 & 2,044 & 2,044 \\
\hline Number of Institutions & 231 & 231 & 231 & 231 \\
\hline AIC & $23,131.86$ & $23,179.63$ & $23,162.98$ & $23,185.60$ \\
\hline BIC & $23,362.39$ & $23,410.16$ & $23,393.51$ & $23,416.13$ \\
\hline
\end{tabular}

Note: Scientific production (dependent variable) includes articles in journals; book chapters; and complete works in annals. Standard error in parentheses. $\left({ }^{* *}\right) p<0.01,\left({ }^{* *}\right) p<0.05,\left({ }^{*}\right) p<0.1$.

Source: Authors' own elaboration. 
Table A5 - Determinants of technological knowledge production in higher education and research institutions in Brazil, estimation through Negative Binomial Model, Panel Data, 2003-2011

\begin{tabular}{|c|c|c|c|c|}
\hline Dependent Variable: PAT & (1) & $(2)$ & (3) & (4) \\
\hline \multirow{2}{*}{ Size of Institution (Students) } & $0.56^{* * *}$ & $0.57^{* * *}$ & $0.56^{* * *}$ & $0.57^{* * *}$ \\
\hline & $(0.11)$ & $(0.11)$ & $(0.11)$ & $(0.11)$ \\
\hline \multirow{2}{*}{ Postgraduation (PROFperPOSTSTUD) } & 0.22 & 0.23 & 0.22 & 0.25 \\
\hline & $(0.16)$ & $(0.16)$ & $(0.16)$ & $(0.16)$ \\
\hline \multirow{2}{*}{ Age of Institution ( $A G E)$} & $0.97^{* *}$ & $1.00^{* *}$ & $0.94^{* *}$ & $0.93^{* *}$ \\
\hline & $(0.41)$ & $(0.41)$ & $(0.41)$ & $(0.40)$ \\
\hline \multirow{2}{*}{$\begin{array}{l}\text { Postgraduate Program in Exact and } \\
\text { Land Sc. }\end{array}$} & $0.02^{* * *}$ & $0.02^{* * *}$ & $0.02^{* * *}$ & $0.02^{* * *}$ \\
\hline & $(0.00)$ & $(0.00)$ & $(0.00)$ & $(0.00)$ \\
\hline \multirow{2}{*}{$\begin{array}{l}\text { Postgraduate Program in } \\
\text { Multidisciplinary }\end{array}$} & $-0.07^{\star *}$ & $-0.06^{* *}$ & $-0.07^{\star * *}$ & $-0.07^{\star * *}$ \\
\hline & $(0.03)$ & $(0.03)$ & $(0.03)$ & $(0.03)$ \\
\hline \multirow{2}{*}{ Postgraduate Program in Biology } & 0.03 & 0.03 & 0.03 & 0.03 \\
\hline & $(0.03)$ & $(0.03)$ & $(0.03)$ & $(0.03)$ \\
\hline \multirow{2}{*}{$\begin{array}{l}\text { Excellence in Exact and Land } S c \text {. } \\
\left(D Q U A L I T Y \_E X A\right)\end{array}$} & $0.30^{* *}$ & $0.31^{* *}$ & $0.31^{* *}$ & $0.31^{* *}$ \\
\hline & $(0.13)$ & $(0.13)$ & $(0.13)$ & $(0.13)$ \\
\hline \multirow{2}{*}{$\begin{array}{l}\text { Excellence in Biology (DQUALITY } \\
B I O)\end{array}$} & -0.05 & -0.05 & -0.04 & -0.03 \\
\hline & $(0.12)$ & $(0.12)$ & $(0.12)$ & $(0.12)$ \\
\hline \multirow{2}{*}{ PUBLIC } & $3.49^{* * *}$ & $3.47^{* * *}$ & $3.50^{* * *}$ & $3.47^{* * *}$ \\
\hline & $(0.29)$ & $(0.29)$ & $(0.29)$ & $(0.29)$ \\
\hline \multirow{2}{*}{$\begin{array}{l}\text { Total Investiments per member of the } \\
\text { teaching staff (TKperPROF) }\end{array}$} & $0.15^{*}$ & & & \\
\hline & $(0.08)$ & & & \\
\hline \multirow{2}{*}{$\begin{array}{l}\text { Total Investiments per students } \\
(\text { TKperSTUD) }\end{array}$} & & $0.34^{* * *}$ & & \\
\hline & & $(0.12)$ & & \\
\hline \multirow{2}{*}{$\begin{array}{l}\text { Investiments in research grants per } \\
\text { member of the teaching staff } \\
(\text { KRperPROF) }\end{array}$} & & & $0.13^{* *}$ & \\
\hline & & & $(0.06)$ & \\
\hline \multirow{2}{*}{$\begin{array}{l}\text { Investiments in research grants per } \\
\text { student (KRperSTUD) }\end{array}$} & & & & $0.24^{* * *}$ \\
\hline & & & & $(0.09)$ \\
\hline \multirow{2}{*}{ Dummy of Year (2003) } & $6.77^{* *}$ & $7.32^{* *}$ & $6.49^{* *}$ & $6.65^{* *}$ \\
\hline & $(3.30)$ & $(3.28)$ & $(3.27)$ & $(3.25)$ \\
\hline \multirow{2}{*}{ Dummy of Year (2004) } & $5.99^{* *}$ & $6.43^{* *}$ & $5.75^{* *}$ & $5.91^{* *}$ \\
\hline & $(2.88)$ & $(2.87)$ & $(2.86)$ & $(2.84)$ \\
\hline \multirow{2}{*}{ Dummy of Year (2005) } & $4.90^{* *}$ & $5.27^{* *}$ & $4.70^{*}$ & $4.83^{* *}$ \\
\hline & $(2.47)$ & $(2.46)$ & $(2.45)$ & $(2.43)$ \\
\hline \multirow{2}{*}{ Dummy of Year (2006) } & $4.00^{*}$ & $4.28^{\star *}$ & $3.84^{*}$ & $3.92^{*}$ \\
\hline & $(2.06)$ & $(2.04)$ & $(2.04)$ & $(2.03)$ \\
\hline \multirow{2}{*}{ Dummy of Year (2007) } & $3.32^{* *}$ & $3.54^{\star \star}$ & $3.18^{\star}$ & $3.24^{* *}$ \\
\hline & $(1.64)$ & $(1.63)$ & $(1.63)$ & $(1.62)$ \\
\hline
\end{tabular}


Table A5 - Determinants of technological knowledge production in higher education and research institutions in Brazil, estimation through Negative Binomial Model, Panel Data, 2003-2011

\begin{tabular}{lcccc}
\hline Dependent Variable: PAT & $(1)$ & $(2)$ & $(3)$ & $(4)$ \\
\hline Dummy of Year (2008) & $2.44^{* *}$ & $2.60^{* *}$ & $2.34^{*}$ & $2.39^{* *}$ \\
& $(1.23)$ & $(1.23)$ & $(1.22)$ & $(1.22)$ \\
Dummy of Year (2009) & $1.47^{*}$ & $1.57^{*}$ & $1.39^{*}$ & $1.40^{*}$ \\
& $(0.82)$ & $(0.82)$ & $(0.82)$ & $(0.81)$ \\
Dummy of Year (2010) & $0.72^{*}$ & $0.76^{*}$ & 0.68 & 0.68 \\
& $(0.42)$ & $(0.42)$ & $(0.42)$ & $(0.41)$ \\
Constant & $-12.29^{* * *}$ & $-12.61^{* * *}$ & $-12.22^{* * *}$ & $-12.29^{* * *}$ \\
Dummies for Research Funding & $(1.96)$ & $(1.97)$ & $(1.95)$ & $(1.94)$ \\
Foundation & Yes & Yes & Yes & Yes \\
Number of Observations & 2,044 & 2,044 & 2,044 & 2,044 \\
Number of Institutions & 231 & 231 & 231 & 231 \\
AIC & $3,048.60$ & $3,042.63$ & $3,048.54$ & $3,044.72$ \\
BIC & $3,273.51$ & $3,267.53$ & $3,273.44$ & $3,269.63$ \\
\hline
\end{tabular}

Note: Standard error in parentheses. $\left({ }^{* * *}\right) p<0.01,\left({ }^{* *}\right) p<0.05,\left({ }^{*}\right) p<0.1$

Source: Authors' own elaboration.

Tabela A6 - Determinants of scientific knowledge production in higher education and research institutions in Brazil, estimation through Negative Binomnial Model, Panel Data, 2003-2011

\begin{tabular}{lcccc}
\hline Variável Dependente: PUB & $(\mathbf{1})$ & $(\mathbf{2})$ & $(\mathbf{3})$ & $\mathbf{( 4 )}$ \\
\hline Size of Institution (Students) & $0.25^{* * *}$ & $0,26^{* * *}$ & $0,26^{* * *}$ & $0,28^{* * *}$ \\
& $(0.04)$ & $(0,04)$ & $(0,04)$ & $(0,04)$ \\
Postgraduation (PROFperPOSTSTUD) & $0.16^{* * *}$ & $0,16^{* * *}$ & $0,16^{* * *}$ & $0,16^{* * *}$ \\
Age of Institution (AGE) & $(0.02)$ & $(0,02)$ & $(0,02)$ & $(0,02)$ \\
Postgraduate Program in Exact and & $0.67^{* * *}$ & $0,67^{* * *}$ & $0,70^{* * *}$ & $0,70^{* * *}$ \\
Land Sc. & $(0.15)$ & $(0,15)$ & $(0,15)$ & $(0,15)$ \\
& 0.00 & 0,00 & 0,00 & 0,00 \\
Postgraduate Program in Humanities & $(0.01)$ & $(0,01)$ & $(0,01)$ & $(0,01)$ \\
Postgraduate Program in & $-0.03^{* * *}$ & $-0,04^{* * *}$ & $-0,04^{* * *}$ & $-0,05^{* * *}$ \\
Multidisciplinary & $(0.01)$ & $(0,01)$ & $(0,01)$ & $(0,01)$ \\
& $-0.07^{* * *}$ & $-0,08^{* * *}$ & $-0,07^{* * *}$ & $-0,08^{* * *}$ \\
Postgraduate Program in Biology & $(0.01)$ & $(0,01)$ & $(0,01)$ & $(0,01)$ \\
Excellence in Exact and Land Sc. & $-0.04^{* * *}$ & $-0,05^{* * *}$ & $-0,04^{* * *}$ & $-0,05^{* * *}$ \\
(DQUALITY_EXA) & $(0.02)$ & $(0,02)$ & $(0,02)$ & $(0,02)$ \\
Excellence in Humanities (DQUALITY_ & $0.55^{* * *}$ & $0.58^{* * *}$ & $0.56^{* * *}$ & $0.60^{* * *}$ \\
HUM) & $(0.05)$ & $(0.05)$ & $(0.05)$ & $(0.06)$ \\
\hline
\end{tabular}




\section{Tabela A6 - Determinants of scientific knowledge production in higher education and research institutions in Brazil, estimation through Negative Binomnial Model, Panel Data, 2003-2011}

\begin{tabular}{|c|c|c|c|c|}
\hline Variável Dependente: PUB & $(1)$ & $(2)$ & (3) & $(4)$ \\
\hline \multirow{2}{*}{$\begin{array}{l}\text { Excellence in Biology (DQUALITY } \\
B I O)\end{array}$} & 0.02 & 0.00 & 0.01 & -0.00 \\
\hline & $(0.07)$ & $(0.07)$ & $(0.07)$ & $(0.07)$ \\
\hline \multirow{2}{*}{ PUBLIC } & $1.33^{* * *}$ & $1.30^{* * *}$ & $1.32^{* * *}$ & $1.23^{\star * *}$ \\
\hline & $(0.12)$ & $(0.12)$ & $(0.12)$ & $(0.12)$ \\
\hline \multirow{2}{*}{$\begin{array}{l}\text { Total Investiments per member of the } \\
\text { teaching staff (TKperPROF) }\end{array}$} & $0.13^{* * *}$ & & & \\
\hline & $(0.02)$ & & & \\
\hline \multirow{2}{*}{$\begin{array}{l}\text { Total Investiments per students } \\
\text { (TKperSTUD) }\end{array}$} & & $0.06^{\star *}$ & & \\
\hline & & $(0.03)$ & & \\
\hline \multirow{2}{*}{$\begin{array}{l}\text { Investiments in research grants per } \\
\text { member of the teaching staff } \\
\text { (KRperPROF) }\end{array}$} & & & $0.07^{* * *}$ & \\
\hline & & & $(0.02)$ & \\
\hline \multirow{2}{*}{$\begin{array}{l}\text { Investiments in research grants per } \\
\text { student (KRperSTUD) }\end{array}$} & & & & -0.01 \\
\hline & & & & $(0.02)$ \\
\hline \multirow{2}{*}{ Dummy of Year (2003) } & $4.61^{\star * *}$ & $4.32^{* * *}$ & $4.67^{* * *}$ & $4.35^{\star * *}$ \\
\hline & $(1.21)$ & $(1.18)$ & $(1.22)$ & $(1.17)$ \\
\hline \multirow{2}{*}{ Dummy of Year (2004) } & $3.92^{* * *}$ & $3.68^{* * *}$ & $3.99^{* * *}$ & $3.71^{* * *}$ \\
\hline & $(1.06)$ & $(1.04)$ & $(1.07)$ & $(1.03)$ \\
\hline \multirow{2}{*}{ Dummy of Year (2005) } & $3.44^{\star * *}$ & $3.24^{* * *}$ & $3.50^{* * *}$ & $3.28^{* * *}$ \\
\hline & $(0.91)$ & $(0.89)$ & $(0.92)$ & $(0.88)$ \\
\hline \multirow{2}{*}{ Dummy of Year (2006) } & $2.91^{\star * *}$ & $2.76^{\star * *}$ & $2.97^{* * *}$ & $2.80^{\star * *}$ \\
\hline & $(0.76)$ & $(0.74)$ & $(0.76)$ & $(0.73)$ \\
\hline \multirow{2}{*}{ Dummy of Year (2007) } & $2.37^{\star * *}$ & $2.26^{* * *}$ & $2.42^{* * *}$ & $2.30^{* * *}$ \\
\hline & $(0.61)$ & $(0.59)$ & $(0.61)$ & $(0.59)$ \\
\hline \multirow{2}{*}{ Dummy of Year (2008) } & $1.71^{* * *}$ & $1.64^{* * *}$ & $1.76^{* * *}$ & $1.67^{* * *}$ \\
\hline & $(0.46)$ & $(0.45)$ & $(0.46)$ & $(0.44)$ \\
\hline \multirow{2}{*}{ Dummy of Year (2009) } & $1.13^{\star * *}$ & $1.08^{* * *}$ & $1.15^{\star * *}$ & $1.11^{\star * *}$ \\
\hline & $(0.31)$ & $(0.30)$ & $(0.31)$ & $(0.30)$ \\
\hline \multirow{2}{*}{ Dummy of Year (2010) } & $0.53^{* * *}$ & $0.52^{* * *}$ & $0.55^{\star * *}$ & $0.53^{\star * *}$ \\
\hline & $(0.16)$ & $(0.16)$ & $(0.16)$ & $(0.15)$ \\
\hline \multirow{2}{*}{ Constant } & $-5.95^{\star * *}$ & $-5.78^{\star * *}$ & $-6.05^{\star * *}$ & $-5.97^{\star * *}$ \\
\hline & $(0.90)$ & $(0.89)$ & $(0.89)$ & $(0.87)$ \\
\hline Dummies of Region & Yes & Yes & Yes & Yes \\
\hline Number of Observations & 2,044 & 2,044 & 2,044 & $2, .044$ \\
\hline Number of Institutions & 231 & 231 & 231 & 231 \\
\hline AIC & $23,068.53$ & $23,114.36$ & $23,097 ., 54$ & $22,969 ., 91$ \\
\hline $\mathrm{BIC}$ & $23,344,04$ & $23,389,87$ & $23,373,05$ & $23,239,38$ \\
\hline
\end{tabular}

Note: Scientific production (dependent variable) includes articles in journals; book chapters; and complete works in annals Standard error in parentheses. $\left(^{* * *}\right) p<0.01,\left({ }^{* *}\right) p<0.05,\left({ }^{*}\right) p<0.1$.

Source: Authors' own elaboration. 


\section{Tabela A7 - Determinants of technological knowledge production in higher education and research institutions in Brazil, estimation through Negative Binomial Model, Panel Data, 2003-2011}

\begin{tabular}{|c|c|c|c|c|}
\hline Dependent Variable: PAT & (1) & (2) & (3) & (4) \\
\hline \multirow{2}{*}{ Size of Institution (Students) } & $0.57^{* * *}$ & $0.58^{* * *}$ & $0.58^{* * *}$ & $0.58^{* * *}$ \\
\hline & $(0.11)$ & $(0.11)$ & $(0.11)$ & $(0.11)$ \\
\hline \multirow{2}{*}{ Postgraduation (PROFperPOSTSTUD) } & 0.22 & 0.23 & 0.22 & 0.25 \\
\hline & $(0.16)$ & $(0.16)$ & $(0.15)$ & $(0.16)$ \\
\hline \multirow{2}{*}{ Age of Institution ( $A G E)$} & $0.93^{* *}$ & $0.96^{\star *}$ & $0.90^{* *}$ & $0.89^{* *}$ \\
\hline & $(0.41)$ & $(0.41)$ & $(0.41)$ & $(0.41)$ \\
\hline \multirow{2}{*}{$\begin{array}{l}\text { Postgraduate Program in Exact and } \\
\text { Land Sc. }\end{array}$} & $0.02^{* * *}$ & $0.02^{* * *}$ & $0.02^{* * *}$ & $0.02^{* * *}$ \\
\hline & $(0.00)$ & $(0.00)$ & $(0.00)$ & $(0.00)$ \\
\hline \multirow{2}{*}{$\begin{array}{l}\text { Postgraduate Program in } \\
\text { Multidisciplinary }\end{array}$} & $-0.07^{* * *}$ & $-0.07^{* *}$ & $-0.07^{* * *}$ & $-0.08^{* * *}$ \\
\hline & $(0.03)$ & $(0.03)$ & $(0.03)$ & $(0.03)$ \\
\hline \multirow{2}{*}{ Postgraduate Program in Biology } & 0.03 & 0.02 & 0.03 & 0.03 \\
\hline & $(0.03)$ & $(0.03)$ & $(0.03)$ & $(0.03)$ \\
\hline \multirow{2}{*}{$\begin{array}{l}\text { Excellence in Exact and Land } S c \text {. } \\
\text { (DQUALITY_EXA) }\end{array}$} & $0.34^{* * *}$ & $0.34^{* * *}$ & $0.34^{* * *}$ & $0.34^{* * *}$ \\
\hline & $(0.13)$ & $(0.13)$ & $(0.13)$ & $(0.13)$ \\
\hline \multirow{2}{*}{$\begin{array}{l}\text { Excellence in Biology (DQUALITY } \\
B I O)\end{array}$} & -0.04 & -0.04 & -0.03 & -0.02 \\
\hline & $(0.12)$ & $(0.12)$ & $(0.12)$ & $(0.12)$ \\
\hline \multirow{2}{*}{ PUBLIC } & $3.55^{* * *}$ & $3.53^{* * *}$ & $3.55^{* * *}$ & $3.52^{* * *}$ \\
\hline & $(0.29)$ & $(0.29)$ & $(0.29)$ & $(0.29)$ \\
\hline \multirow{2}{*}{$\begin{array}{l}\text { Total Investiments per member of the } \\
\text { teaching staff (TKperPROF) }\end{array}$} & $0.15^{\star}$ & & & \\
\hline & $(0.08)$ & & & \\
\hline \multirow{2}{*}{$\begin{array}{l}\text { Total Investiments per students } \\
\text { (TKperSTUD) }\end{array}$} & & $0.34^{* * *}$ & & \\
\hline & & $(0.11)$ & & \\
\hline \multirow{2}{*}{$\begin{array}{l}\text { Investiments in research grants per } \\
\text { member of the teaching staff } \\
\text { (KRperPROF) }\end{array}$} & & & $0.13^{* *}$ & \\
\hline & & & $(0.06)$ & \\
\hline \multirow{2}{*}{$\begin{array}{l}\text { Investiments in research grants per } \\
\text { student (KRperSTUD) }\end{array}$} & & & & $0.25^{* * *}$ \\
\hline & & & & $(0.09)$ \\
\hline \multirow{2}{*}{ Dummy of Year (2003) } & $6.44^{*}$ & $7.05^{* *}$ & $6.18^{*}$ & $6.36^{\star}$ \\
\hline & $(3.32)$ & $(3.30)$ & $(3.29)$ & $(3.26)$ \\
\hline \multirow{2}{*}{ Dummy of Year (2004) } & $5.70^{* *}$ & $6.19^{* *}$ & $5.47^{*}$ & $5.66^{* *}$ \\
\hline & $(2.90)$ & $(2.88)$ & $(2.88)$ & $(2.85)$ \\
\hline \multirow{2}{*}{ Dummy of Year (2005) } & $4.66^{*}$ & $5.06^{* *}$ & $4.47^{\star}$ & $4.62^{*}$ \\
\hline & $(2.48)$ & $(2.47)$ & $(2.46)$ & $(2.44)$ \\
\hline \multirow{2}{*}{ Dummy of Year (2006) } & $3.79^{*}$ & $4.11^{* *}$ & $3.63^{*}$ & $3.74^{*}$ \\
\hline & $(2.07)$ & $(2.06)$ & $(2.05)$ & $(2.04)$ \\
\hline \multirow{2}{*}{ Dummy of Year (2007) } & $3.15^{\star}$ & $3.40^{* *}$ & $3.03^{*}$ & $3.10^{*}$ \\
\hline & $(1.65)$ & $(1.64)$ & $(1.64)$ & $(1.63)$ \\
\hline
\end{tabular}


Tabela A7 - Determinants of technological knowledge production in higher education and research institutions in Brazil, estimation through Negative Binomial Model, Panel Data, 2003-2011

\begin{tabular}{lcccc}
\hline Dependent Variable: PAT & $(\mathbf{1})$ & $(\mathbf{2})$ & $(3)$ & $(\mathbf{4})$ \\
\hline Dummy of Year (2008) & $2.31^{*}$ & $2.49^{* *}$ & $2.22^{*}$ & $2.28^{*}$ \\
& $(1.24)$ & $(1.23)$ & $(1.23)$ & $(1.22)$ \\
Dummy of Year (2009) & $1.38^{*}$ & $1.49^{*}$ & 1.30 & 1.31 \\
& $(0.83)$ & $(0.82)$ & $(0.82)$ & $(0.82)$ \\
Dummy of Year (2010) & 0.67 & $0.71^{*}$ & 0.63 & 0.63 \\
& $(0.42)$ & $(0.42)$ & $(0.42)$ & $(0.42)$ \\
Constant & $-5.95^{* * *}$ & $-5.78^{* * *}$ & $-6.05^{* * *}$ & $-5.97^{* * *}$ \\
Dummies of Region & $(0.90)$ & $(0.89)$ & $(0.89)$ & $(0.87)$ \\
Number of Observations & Yes & Yes & Yes & Yes \\
Number of Institutions & 2,044 & 2,044 & 2,044 & 2,044 \\
AIC & 231 & 231 & 231 & 231 \\
BIC & $3,034.25$ & $3,028.03$ & $3,037.10$ & $3,043.79$ \\
\hline \hline
\end{tabular}

Note: Standard error in parentheses. ${ }^{* * *} p<0.01,{ }^{*} p<0.05,{ }^{*} p<0.1$

Source: Authors' own elaboration.

\section{Table A8 - List of higher education and research institutions in the sample}

\section{Institution}

Alagoas State University of Health Sciences (UNICISAL)

Amazonas State University (UEA)

Anhembi Morumbi University (UAM)

Bahia School of Medicine and Public Health (EBMSP)

Bandeirante de São Paulo University (UNIBAN)

Barão de Mauá University Center (CBM)

Boa Viagem College (FBV)

Camilo Castelo Branco University (UNICASTELO)

Campos de Andrade University Center (UNIANDRADE)

Cândido Mendes University (UCAM)

Catholic College of Tocantins (FACTO)

Catholic University of Brasília (UCB)

Catholic University of Pelotas (UCPEL)

Catholic University of Pernambuco (UNICAP)

Catholic University of Petrópolis (UCP)

Catholic University of Salvador (UCSAL)

Catholic University of Santos (UNISANTOS)

Center of Technological Teaching Institute 
Table A8 - List of higher education and research institutions in the sample

Institution

Cidade de São Paulo University (UNICID)

College of Medicine Foundation (FFM)

Community University of Chapecó Region (UNICHAPECÓ)

Cruzeiro do Sul University (UNICSUL)

Dom Bosco Catholic University (UCDB)

Dom Bosco College (DOM BOSCO)

Dr. Francisco Maeda College of Ituverara (FAFRAM)

Ensitec School and College (ENSITEC)

Estácio de Sá University

Euripedes University Center of Marília (UNIVEM)

Euro-American University Center (UNIEURO)

Evangelical College of Paraná (FEPAR)

Federal Institute of Bahia (IFBA)

Federal Rural University of Amazônia (UFRA)

Federal Rural University of Pernambuco (UFRPE)

Federal Rural University of Rio de Janeiro (UFRRJ)

Federal Rural University of the Semi-arid Region (UFERSA)

Federal Technological University of Paraná (UTFPR)

Federal University of ABC (UFABC)

Federal University of Acre (UFAC)

Federal University of Alagoas (UFAL)

Federal University of Alfenas (UNIFAL)

Federal University of Amapa (UNIFAP)

Federal University of Amazonas (UFAM)

Federal University of Bahia (UFBA)

Federal University of Campina Grande (UFCG)

Federal University of Ceará (UFC)

Federal University of Espírito Santo (UFES)

Federal University of Goiás (UFG)

Federal University of Grande Dourados (UFGD)

Federal University of Health Sciences of Porto Alegre (UFCSPA)

Federal University of Itajuba (UNIFEI)

Federal University of Juiz de Fora (UFJF)

Federal University of Lavras (UFLA)

Federal University of Maranhão (UFMA)

Federal University of Mato Grosso (UFMT)

Federal University of Mato Grosso do Sul (UFMS)

Federal University of Minas Gerais (UFMG) 
Table A8 - List of higher education and research institutions in the sample

Institution

Federal University of Ouro Preto (UFOP)

Federal University of Pampa (UNIPAMPA)

Federal University of Para (UFPA)

Federal University of Paraíba (UFPB)

Federal University of Paraná (UFPR)

Federal University of Pelotas (UFPEL)

Federal University of Pernambuco (UFPE)

Federal University of Piauí (UFPI)

Federal University of Recôncavo Baiano (UFRB)

Federal University of Rio de Janeiro (UFRJ)

Federal University of Rio Grande (FURG)

Federal University of Rio Grande do Norto (UFRN)

Federal University of Rio Grande do Sul (UFRGS)

Federal University of Rondonia Foundation (UNIR)

Federal University of Roraima (UFRR)

Federal University of Santa Catarina (UFSC)

Federal University of Santa Maria (UFSM)

Federal University of São Carlos (UFSCAR)

Federal University of São João Del-Rei (UFSJ)

Federal University of São Paulo (UNIFESP)

Federal University of Sergipe (UFS)

Federal University of the State of Rio de Janeiro (UNIRIO)

Federal University of Tocantins (UFT)

Federal University of Triêngulo Mineiro (UFTM)

Federal University of Uberlândia (UFU)

Federal University of Vale do São Francisco (UNIVASF)

Federal University of Vales do Jequitinhonha e Mucuri (UFVJM)

Federal University of Vicosa (UFV)

Feevale University (FEEVALE)

FIEO University Center (UNIFIEO)

Fluminense Federal University (UFF)

Franciscan University Center of Paraná (UNIFAE)

Franciscan University Center

FUMEC University (FUMEC)

Fundação Getúlio Vargas (FGV)

Gama Filho University (UGF)

Guaraí College (FAG)

Guarulhos University (UNG) 
Table A8 - List of higher education and research institutions in the sample

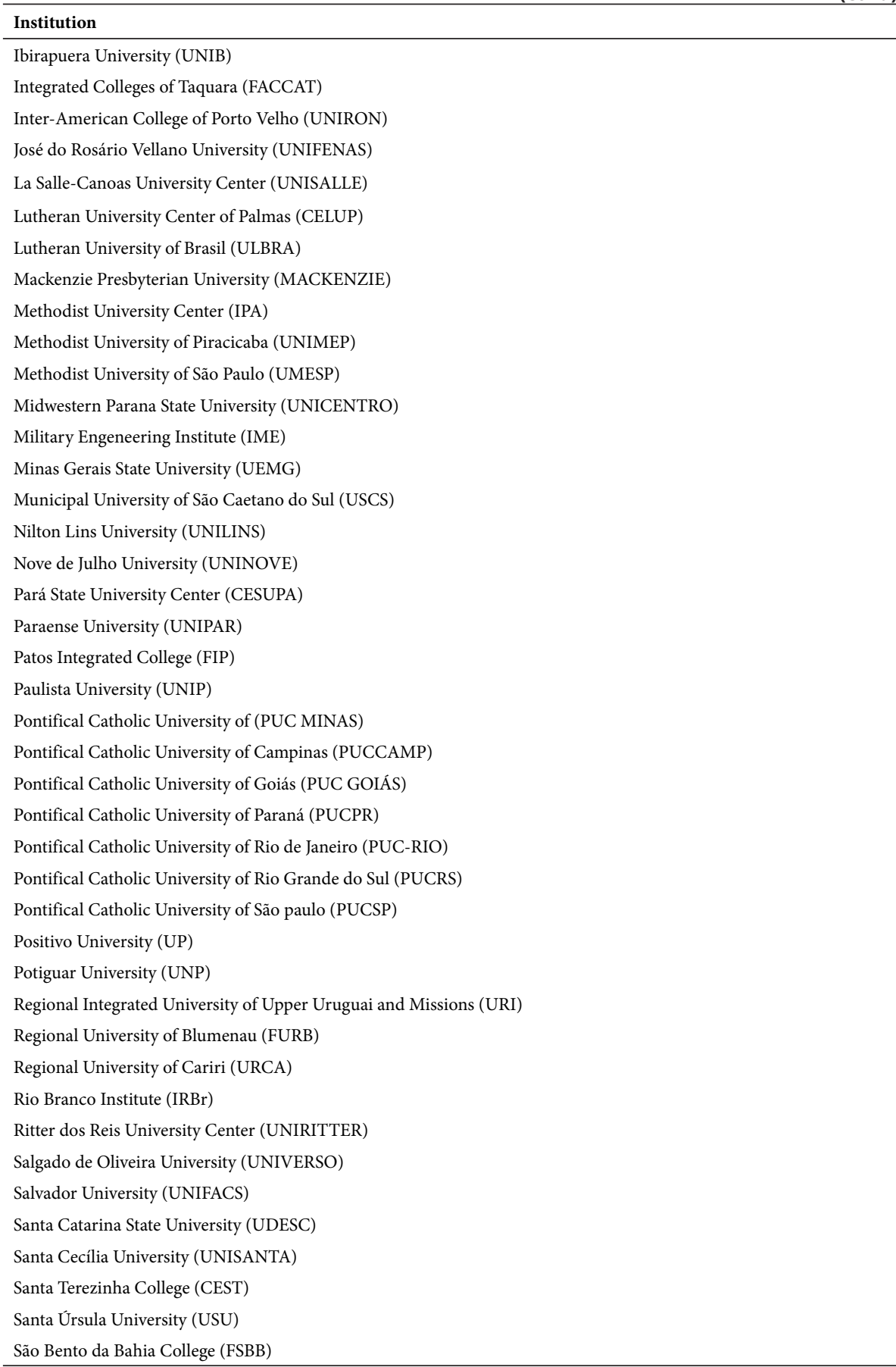


Table A8 - List of higher education and research institutions in the sample

Institution

São Francisco University (USF)

São Judas Tadeu University

São Paulo State Technoloical College (FATECSP)

São Paulo State University (UNESP)

Seama College (SEAMA)

Sorocaba University (UNISO)

State University of Alagoas (UNEAL)

State University of Bahia (UNEB)

State University of Ceará (UECE)

State University of Feira de Santana (UEFS)

State University of Goiás (UEG)

State University of Londrina (UEL)

State University of Maranhão (UEMA)

State University of Maringá (UEM)

State University of Mato Grosso (UNEMAT)

State University of Mato Grosso do Sul (UFMS)

State University of Montes Claros (UNIMONTES)

State University of Northern Paraná (UENP)

State University of Northern Rio de Janeiro (UFNF)

State University of Pará (UEPA)

State University of Paraíba (UEPB)

State University of Paraná (UEPR)

State University of Piauí (UESPI)

State University of Ponta Grossa (UEPG)

State University of Rio de Janeiro (UERJ)

State University of Rio Grande do Norte (UERN)

State University of Rio Grande do Sul (UERGS)

State University of Roraima (UERR)

State University of Santa Cruz (UESC)

State University of Southwestern Bahia (UESB)

Superior School of Health Sciences (ESCS)

Technological Institute of Aeronautics (ITA)

Technological Institute of Pernambuco (ITPE)

Teresa D'Avilda Integrated Colleges (FATEA)

Thereza Porto Marques College of Education and Technology

Tiradentes University (UNIT)

Tuiuti do Paraná University (UTP)

Unihorizontes University Center (UNIHORIZONTES)

Unisinos University (UNISINOS)

UNIVATES University Center

University Center Augusto da Motta (UNISUAM)

University Center of Anápolis - UniEVANGÉLICA 
Table A8 - List of higher education and research institutions in the sample

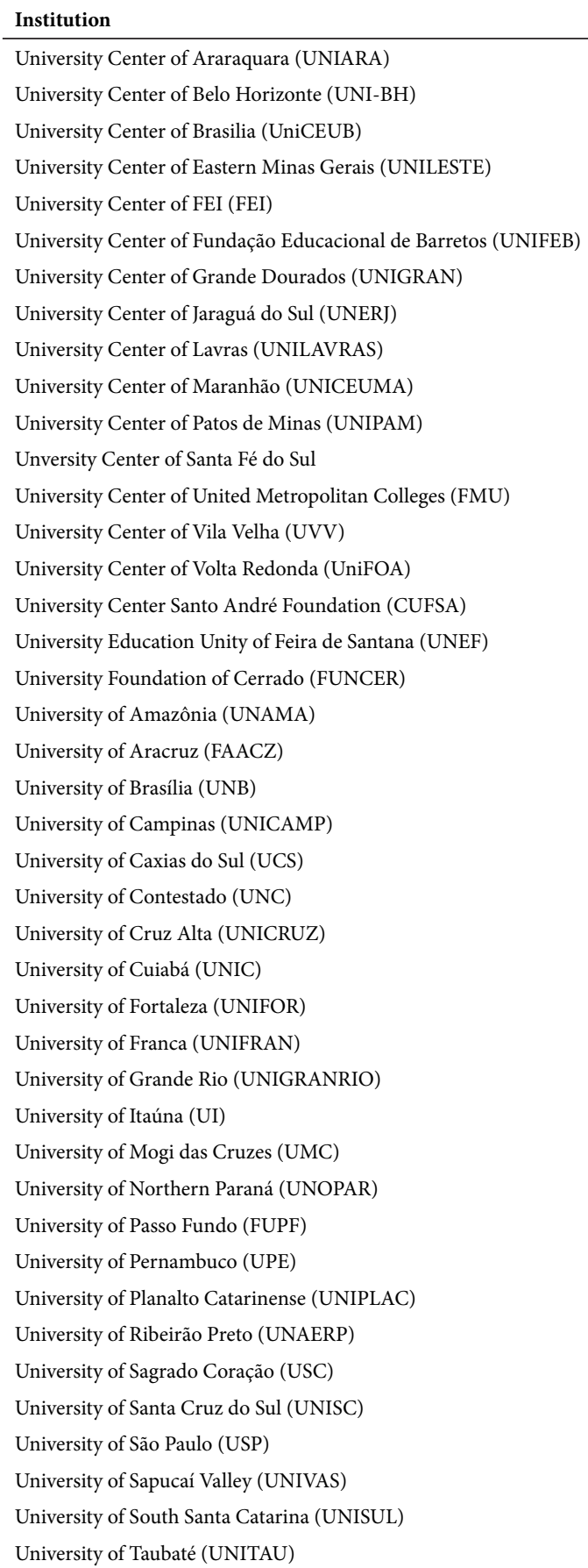




\title{
Table A8 - List of higher education and research institutions in the sample
}

\author{
Institution \\ University of the Juinville Region (UNIVILLE) \\ University of the Region of Campanha (URCAMP) \\ University of the Valley of Itajaí (UNIVALI) \\ University of the Valley of Paraíba (UNIVAP) \\ University of Tocantins (UNITINS) \\ University of Uberada (UNIUBE) \\ University of Western Santa Catarina (UNOESC) \\ University of Western São Paulo (UNOESTE) \\ University Santo Amaro (UNISA) \\ Vale do Acaraú State University (UVA-CE) \\ Vale do Rio Doce University (UNIVALE) \\ Veiga de Almeida University (UVA) \\ Vitória College of Law (FDV) \\ Western Paraná State University (UNIOESTE)
}

Source: Authors' own elaboration.

\section{Table A9 - List of state-level funding agencies}

Fundação de Amparo a Ciência e Tecnologia do Estado de Pernambuco (FACEPE)

Fundação de Apoio à Pesquisa do Distrito Federal (FAPDF)

Fundação de Amparo à Pesquisa do Estado do Amazonas (FAPEAM)

Fundação de Amparo à Pesquisa do Amapá (FAPEAP)

Fundação de Amparo à Pesquisa do Estado de Goiás (FAPEG)

Fundação de Amparo à Pesquisa e ao Desenvolvimento Científico e Tecnológico do Maranhão (FAPEMA)

Fundação de Amparo à Pesquisa do Estado do Mato Grosso (FAPEMAT)

Fundação de Amparo à Pesquisa do Estado de Minas Gerais (FAPEMIG)

Fundação de Amparo à Pesquisa do Piauí (FAPEPI)

Fundação de Amparo à Pesquisa do Rio Grande do Sul (FAPERGS)

Fundação de Amparo à Pesquisa do Rio de Janeiro (FAPERJ)

Fundação de Apoio à Pesquisa do Rio Grande do Norte (FAPERN)

Fundação de Amparo ao Desenvolvimento das Ações Científicas e Tecnológicas e à Pesquisa (FAPERO)

Fundação de Amparo à Pesquisa do Estado da Bahia (FAPESB)

Fundação de Amparo à Pesquisa e Inovação de Santa Catarina (FAPESC)

Fundação de Amparo à Pesquisa do Estado de São Paulo (FAPESP)

Fundação Amazônia de Amparo a Estudos e Pesquisas (FAPESPA)

Fundação de Apoio à Pesquisa do Estado da Paraíba (FAPESQ)

Fundação Araucária (FAPPR)

Source: Authors' own elaboration. 